OPEN ACCESS

Edited by:

Miriam Manook,

University of Cambridge,

United Kingdom

Reviewed by:

Marina Noris,

Mario Negri Pharmacological

Research Institute (IRCCS), Italy

Stefan Reuter,

University Hospital Münster, Germany

*Correspondence:

Weijun Qin

qinwj@fmmu.edu.cn

Specialty section:

This article was submitted to Alloimmunity and Transplantation,

a section of the journal

Frontiers in Immunology

Received: 09 November 2021

Accepted: 31 January 2022

Published: 25 February 2022

Citation:

Qi R and Qin W (2022) Role of

Complement System in Kidney

Transplantation: Stepping From Animal Models to Clinical Application.

Front. Immunol. 13:811696.

doi: 10.3389/fimmu.2022.811696

\section{Role of Complement System in Kidney Transplantation: Stepping From Animal Models to Clinical Application}

\author{
Ruochen Qi and Weijun Qin* \\ Department of Urology, Xijing Hospital, Fourth Military Medical University, Xi'an, China
}

Kidney transplantation is a life-saving strategy for patients with end-stage renal diseases. Despite the advances in surgical techniques and immunosuppressive agents, the longterm graft survival remains a challenge. Growing evidence has shown that the complement system, part of the innate immune response, is involved in kidney transplantation. Novel insights highlighted the role of the locally produced and intracellular complement components in the development of inflammation and the alloreactive response in the kidney allograft. In the current review, we provide the updated understanding of the complement system in kidney transplantation. We will discuss the involvement of the different complement components in kidney ischemiareperfusion injury, delayed graft function, allograft rejection, and chronic allograft injury. We will also introduce the existing and upcoming attempts to improve allograft outcomes in animal models and in the clinical setting by targeting the complement system. Keywords: complement activation, kidney transplantation, ischemia-reperfusion injury, delayed graft function,
T-cell-mediated rejection, antibody-mediated rejection, eculizumab, C1-INH

\section{INTRODUCTION}

Kidney transplantation is the preferred treatment for patients with end-stage renal diseases (ESRDs), which greatly improves their quality of life. The established surgical procedure and the development of immunosuppressive therapy have largely reduced the perioperative complications. However, long-term survival of kidney allografts remains challenging. Kidney ischemia-reperfusion injury (IRI), delayed graft function (DGF), T-cell- and B-cell-mediated rejection, and chronic allograft injury could all contribute to graft loss. The current perioperative induction therapy and immunosuppressive agents mainly target the activation of $\mathrm{T}$ cells to eliminate T-cell-mediated rejection (TCMR). However, growing evidence has shown that the complement system, part of the innate immune response, is also activated in kidney transplantation. In the current review, we will first introduce the updated knowledge on the complement system, including their components, receptors, and regulators. Then, we will discuss the roles of the different complement factors in kidney IRI, DGF, allograft rejection, and chronic allograft injury. We will also discuss the existing and upcoming therapies targeting the complement components in the scenario of kidney transplantation. 


\section{OVERVIEW OF THE COMPLEMENT SYSTEM}

The complement system consists of over 50 circulating, locally expressed, membrane-bound, and intracellular proteins (1). The complement factors, their cleaved fragments, corresponding receptors, and a wide range of regulators serve as integral parts of the innate immune response. Complement proteins circulating in the serum are mostly synthesized in the liver and are activated by a series of serine proteases in a cascade manner $(2,3)$. The cascade can be triggered by three different pathways: the classical pathway $(\mathrm{CP})$, the alternative pathway (AP), and the lectin pathway $(\mathrm{LP})(4,5)$. Different pathways converge at the formation of the C3 convertase, which leads to the assembly of the C5 convertase and C5b-9, also known as the membrane attack complex (MAC) (3) (Figure 1).

\section{Initiation Phase}

Three pathways adopt different strategies in sensing the activation signals (6-8). Priming of the CP relies on the

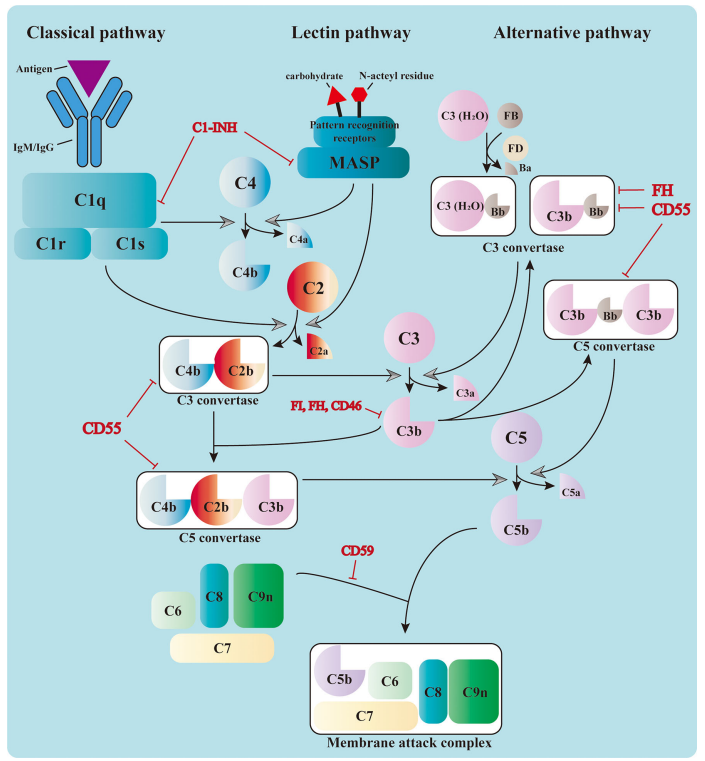

FIGURE 1 | Activation of the complement cascade. The complement system could be triggered by the classical pathway, the lectin pathway, and the alternative pathway. The classical pathway is activated by the binding of $\mathrm{C} 1 \mathrm{q}$ to the immunocomplex, which leads to the formation of the $\mathrm{C} 1 \mathrm{complex}$. The latter cleaves C4 and C2 and assembles the C3 convertase, C4b2b. The serine proteases of the lectin pathway, mannose-binding lectin-associated serine proteases (MASPs), are activated by the recognition of carbohydrate and $\mathrm{N}$-acteyl residues by the pattern recognition receptors. They also cleave C4 and C2 and form the same C3 convertase. The C3 convertase in the alternative pathway includes the initial $\mathrm{C} 3\left(\mathrm{H}_{2} \mathrm{O}\right) \mathrm{Bb}$ and the latter $\mathrm{C} 3 \mathrm{bBb}$ in the amplification phase. All three pathways converge at the cleavage of C3. The cleaved fragment C3b further adds to the C3 convertases and forms the $\mathrm{C} 5$ convertases (C4b2b3b or $\mathrm{C} 3 \mathrm{bBb} 3 \mathrm{~b})$, which cleave $\mathrm{C} 5$ into $\mathrm{C} 5 \mathrm{a}$ and $\mathrm{C} 5 \mathrm{~b}$. The latter leads to the formation of the membrane attack complex (MAC) together with C6, C7, C8, and C9. The complement cascade is also regulated by a variety of membrane-bound and plasma proteins to avoid uncontrolled activation. recognition of immunocomplexes [antigen bound to immunoglobulin $\mathrm{M}$ (IgM) or immunoglobulin $\mathrm{G}(\mathrm{IgG})$ ] by C1q, which leads to the sequent activation of $\mathrm{C} 1 \mathrm{r}$ and $\mathrm{C} 1 \mathrm{~s}$. The latter is responsible for the cleavage of C4 and C2 into small fragments (C4a and $\mathrm{C} 2 \mathrm{a})$ and large ones (C4b and $\mathrm{C} 2 \mathrm{~b})$. Large fragments are further deposited on the cell surface and form the C3 convertase C4b2b (1). The LP shares the same C3 convertase with the $\mathrm{CP}$; however, it is activated through the recognition of bacterial surface carbohydrate or $N$-acteyl residues by pattern recognition molecules, including mannose-binding lectin (MBL), ficolins, and collectins (9). This leads to the activation of MBLassociated serine proteases (MASPs), which can also cleave C4 and $\mathrm{C} 2$ and prompt the formation of $\mathrm{C} 3$ convertase. The activation of the AP is different from that of the other two. It relies on the spontaneous low-rate hydrolysis of the circulating C3 molecule in the fluid phase, a process known as "tickover." The resulting $\mathrm{C} 3\left(\mathrm{H}_{2} \mathrm{O}\right)$ binds to factor $\mathrm{B}(\mathrm{FB})$ to form $\mathrm{C} 3\left(\mathrm{H}_{2} \mathrm{O}\right)$ $\mathrm{Bb}$ with the cleavage of factor $\mathrm{D}(\mathrm{FD}) . \mathrm{C} 3\left(\mathrm{H}_{2} \mathrm{O}\right) \mathrm{Bb}$ is the initial $\mathrm{C} 3$ convertase of the $\mathrm{AP}$, which produces more $\mathrm{C} 3 \mathrm{~b}$ in solution. These $\mathrm{C} 3 \mathrm{~b}$ can be deposited on nearby surfaces and bind FB to form $\mathrm{C} 3 \mathrm{bBb}$, the amplification C3 convertase of the AP (10). This process is accelerated and amplified by the presence of pathogen surfaces and properdin, which prolongs the survival of $\mathrm{C} 3 \mathrm{~b}$ from inactivation (11). Moreover, the C3b produced from the CP and LP serves as the platform for the new AP C3 convertases and forms a positive feedback loop.

\section{Activation Phase}

The formation of $\mathrm{C} 3$ convertase initiates the activation cascade of the complement system. $\mathrm{C} 3$ convertase $(\mathrm{C} 4 \mathrm{~b} 2 \mathrm{~b}$ or $\mathrm{C} 3 \mathrm{bBb})$ cleaves $\mathrm{C} 3$ into $\mathrm{C} 3 \mathrm{a}$ and $\mathrm{C} 3 \mathrm{~b}$, the latter of which adds to the $\mathrm{C} 3$ convertase and assembles the $\mathrm{C} 5$ convertase $(\mathrm{C} 4 \mathrm{~b} 2 \mathrm{~b} 3 \mathrm{~b}$ or C3bBb3b) (12). The C5 convertase cleaves C5 and leads to the production of $\mathrm{C} 5 \mathrm{a}$ and $\mathrm{C} 5 \mathrm{~b}$, the latter of which contributes to the assembly of MAC together with C6, C7, C8, and C9 (13). The MAC penetrates and forms $10-\mathrm{nm}$ pores on the cell membrane, resulting in fluid and ion leakage and, eventually, cell death (14). The formation of MAC exerts direct cytolytic effects on target cells and releases abundant cell components, which can further activate the pattern recognition molecules and amplify the inflammatory response.

Apart from cytolysis, complement components also fulfill their roles through other mechanisms, among which the proinflammatory and opsonization effects are the most recognized. The small cleavage products, such as $\mathrm{C} 3 \mathrm{a}, \mathrm{C} 4 \mathrm{a}$, and $\mathrm{C} 5 \mathrm{a}$, are known as anaphylatoxins because of their ability to induce vasodilation, histamine release, and vascular permeability enhancement. These molecules also mediate the chemotaxis and activation of leukocytes (especially macrophages and neutrophils) by binding to the corresponding receptors, boosting the inflammatory response (15). The large products of serine protease cleavage, usually ending with a " $b$ " in their names, are known as the opsonins, including $\mathrm{C} 3 \mathrm{~b}, \mathrm{iC} 3 \mathrm{~b}, \mathrm{C} 3 \mathrm{~d}$, $\mathrm{C} 4 \mathrm{~b}$, and C4d, among others (16). These fragments are deposited on the cell surfaces and mark them for phagocytosis by interacting with different complement receptors, a process known as opsonization. 


\section{Complement Regulatory Factors}

To avoid uncontrolled activation of the complement cascade and prevent its cytolytic effect on host cells, the system is also regulated by an exquisite network consisting of a variety of membrane-bound and plasma proteins. The membrane-bound complement regulators include CD46 (also known as membrane cofactor protein, MCP), CD55 (also known as decay accelerating factor, DAF), CD59, and CR1 (11). CD46, as well as its counterpart Crry in mice, acts as a cofactor for factor I (FI), which mediates the cleavage of $\mathrm{C} 3 \mathrm{~b}$ into iC $3 \mathrm{~b}$ and interrupts the assembly of C3 convertase (17). Specific ablation of Crry in tubular epithelial cells (TECs) has been reported to deteriorate the kidney IRI in mice (18). CD55 (DAF) is named on the basis of its decay accelerating activity, which impairs the activity of the $\mathrm{C} 3$ and $\mathrm{C} 5$ convertases in both the $\mathrm{CP}$ and $\mathrm{AP}$ (19). CD59 interrupts the formation of MAC by blocking the association of C9 with C5b-8 (19), preventing its cytolytic effect. Deficiency of CD55 and CD59 leads to the abnormal activation of the complement cascade and the formation of MAC on red blood cells. This results in intracellular hemolysis, which is known as paroxysmal nocturnal hemoglobinuria (20). CR1 also possesses the decay accelerating activity and acts as a cofactor of FI (21).

The complement regulatory proteins in the plasma include factor $\mathrm{H}(\mathrm{FH}), \mathrm{FI}$, and $\mathrm{C} 1$ inhibitor (C1-INH), among others. As mentioned above, FI inhibits the formation of complement convertase by cleaving $\mathrm{C} 3 \mathrm{~b}$ and $\mathrm{C} 4 \mathrm{~b}$, with the presence of other cofactors. $\mathrm{FH}$ possesses the decay accelerating activity toward the $\mathrm{C} 3$ convertase of $\mathrm{AP}$ and also acts as the cofactor of FI (22). C1-INH directly inactivates the serine proteases needed for the complement activation, such as $\mathrm{C} 1 \mathrm{r}, \mathrm{C} 1 \mathrm{~s}$, and MASPs (23). Apart from these inhibitory regulatory proteins, properdin is the only positive regulator in this process, which can stabilize $\mathrm{C} 3 \mathrm{bBb}$ and $\mathrm{C} 3 \mathrm{bBb} 3 \mathrm{~b}$ from inactivation (24).

\section{Complement Receptors}

Complement receptors are also indispensable parts of the complement system. The majority of the complement fragments bind to their receptors for corresponding functions. These receptors could be divided into two categories: the complement receptors (CR1, CR2, CR3, and CR4) and the anaphylatoxin receptors (C3aR, C5aR1, and C5aR2) (Table 1). Depending on where it is expressed, the functions of CR1 are dynamic $(25,26)$. Through binding to $\mathrm{C} 3 \mathrm{~b}$ and $\mathrm{C} 4 \mathrm{~b}$ on the immunocomplex, CR1 augments the opsonization activity of phagocytes (21). It has also been reported to modulate the activity of adaptive immune cells, such as B cells (25). However, CR1 also inhibits complement activation in several ways. Firstly, CR1 destabilizes the C 3 and C 5 convertases by occupying C3b and C4b. Secondly, it serves as an MBL receptor and dampens the activation of the LP. Thirdly, CR1 has been reported to possess cofactor activity in FI-mediated C3b degradation (21). CR2 is expressed on B cells and is closely related to B-cell activation and antibody production (36-38). CR3 and CR4 both belong to the integrin superfamily of adhesion proteins and share the same $\beta$-unit CD18 (27). They are responsible for opsonization by binding to their ligands $\mathrm{C} 3 \mathrm{~b} /$ iC3b $(28,39,40)$ and are also involved in cell adhesion activity. Both receptors are mainly expressed on myeloid-derived cells, such as monocytes/macrophages; however, studies have shown that they also appear on certain lymphocytes (29).

Anaphylatoxin receptors, as the name suggests, bind to the anaphylatoxins $\mathrm{C} 3 \mathrm{a}$ and $\mathrm{C} 5 \mathrm{a}$ for proper functions. C3aR and C5aR1 are expressed mainly on immune cells, but are also found on other parenchymal cells, such as TECs (41). Ligation of C3aR and C5aR1 mediates neutrophil and macrophage chemotaxis and orchestrates the inflammation process $(31,42,43)$. However, the role of C5aR2 is more complicated (44). C5aR2 was first discovered as a decoy receptor for $\mathrm{C} 5 \mathrm{a}$ and therefore inhibits the

TABLE 1 | Expression and function of complement receptors.

\begin{tabular}{|c|c|c|c|}
\hline & Ligand & Expression & Function \\
\hline $\begin{array}{l}\text { CR1 } \\
\text { (CD35) }\end{array}$ & C3b, C4b, MBL, ficolin, C1a & $\begin{array}{l}\text { Erythrocytes, neutrophils, monocytes, } \\
\text { macrophages, dendritic cells, T cells, } \\
\text { B cells }\end{array}$ & $\begin{array}{l}\text { Destabilizes C } 3 \text { and C5 convertase; acts as a cofactor of Fl; inhibits LP activation; } \\
\text { clearance of immunocomplex; opsonization; inhibits T-cell and B-cell activation (25, } \\
\text { 26) }\end{array}$ \\
\hline $\begin{array}{l}\text { CR2 } \\
\text { (CD21) }\end{array}$ & $\begin{array}{l}\text { C3d, C3dg, iC3b, gp350 of } \\
\text { Epstein-Barr virus, CD23, } \\
\text { IFN- } \gamma\end{array}$ & $\begin{array}{l}\text { B cells, follicular dendritic cells, } \\
\text { T cells, epithelial cells }\end{array}$ & Co-receptor of B-cell activation; antigen uptake and presentation \\
\hline $\begin{array}{l}\text { CR4 } \\
\text { (CD11C/ } \\
\text { CD18) }\end{array}$ & C3b, iC3b, fibrinogen, ICAMs & $\begin{array}{l}\text { Dendritic cells, monocytes, } \\
\text { macrophages, neutrophils, NK cells, } \\
\text { T cells, microglia }\end{array}$ & Opsonization; cell adhesion $(27,28)$ \\
\hline C3aR & С3а & $\begin{array}{l}\text { Granulocytes, monocytes, } \\
\text { macrophages, parenchymal cells }\end{array}$ & Chemotaxis; granule enzyme release; increase in vascular permeability \\
\hline C5aR1 & C5a & $\begin{array}{l}\text { Neutrophils, monocytes, } \\
\text { macrophages, parenchymal cells }\end{array}$ & Chemotaxis; granule enzyme release; increase in vascular permeability $(13,30)$ \\
\hline
\end{tabular}

MBL, mannose-binding lectin; FI, factor I; LP, lectin pathway; ICAMs, intercellular adhesion molecules; NK, natural killer. 
pro-inflammatory $\mathrm{C} 5 \mathrm{a}-\mathrm{C} 5 \mathrm{aR} 1$ signaling. However, studies have shown that the activation of $\mathrm{C} 5 \mathrm{aR} 2$ also favors inflammatory response in certain occasions, for example, in the context of kidney IRI $(45,46)$. Moreover, recent findings in the intracellular complement system indicated the regulatory role of C5aR2 in Tcell metabolism (16), suggesting that C5aR2 acts more than a decoy receptor. Therefore, further investigation is needed to define its role in different disease models and cell types.

Taken together, the complement system was first discovered as part of the innate immune response against pathogens. Over the past decades, growing evidence in this field has greatly enriched the complement family. Also, our understanding toward complement activation has advanced beyond pathogen clearance and host defense. Numerous studies showed that complement activation is also involved in the recognition and clearance of injured host cells, therefore maintaining homeostasis. This process is achieved through the recognition of endogenous damage-associated molecular patterns (DAMPs). Moreover, various complement components and receptors bridge the innate and adaptive immune systems through contributing to the regulation of $\mathrm{T}$ cells and $\mathrm{B}$ cells.

\section{INVOLVEMENT OF COMPLEMENT ACTIVATION IN KIDNEY IRI}

\section{Complement Pathway Triggered in Kidney IRI}

IRI is the inevitable process during kidney transplantation, which predisposes kidney allograft to DGF and rejection. The involvement of the complement system in IRI is no new concept and has been extensively studied in animal models in the past decades. Although the majority of the complement components circulating in the serum are synthesized in the liver, they can also be produced by kidney parenchymal cells, such as TECs. These locally generated complement factors play a more critical role in kidney IRI than the circulating ones $(3,47,48)$. This was demonstrated by the fact that the kidney isograft from C3-deficient mice showed only mild reperfusion damage when transplanted into C3-positive recipient mice, in which the complement components could still be constantly produced by the recipient's liver (49). Inhibition of the expression of $\mathrm{C} 3$ with small interfering RNA (siRNA) in kidney could also ameliorate IRI $(50,51)$. As mentioned above, the cleavage cascade of the complement system can be triggered by three different pathways. Earlier studies indicated that the AP might be predominant during kidney IRI $(52,53)$. This arose from the observation that pharmacological or genetic ablation of $\mathrm{FB}$, which abolished the AP convertases, ameliorated kidney IRI $(7,46,54)$. On the other hand, inhibition of $\mathrm{FH}$, the negative regulator of the AP, aggravated kidney injury $(22,55)$. More recent studies have turned their attention to the activation of the LP in kidney IRI since DAMPs exposed on kidney parenchymal cells were ideal activators of the LP (56). The inhibition of MBL, the LP initiator, alleviated the pathological injury and the inflammatory response induced by IRI. Studies have shown that the binding of MBL to the cell surface of TECs and the following internalization led to direct cell death in tubular cells, aggravating kidney injury (57). Moreover, mouse kidney allografts with MASP-2 deficiency also showed better outcomes after transplantation through LP inhibition (8). Recent findings have also highlighted the role of a novel LP initiator, collectin-11, which is a soluble lectin molecule expressed in the kidney. Collectin-11 binds to the fucosylated ligand exposed at the ischemic sites and activates the LP (3). Exogenous delivery of L-fucose, a collectin-11 ligand, protected against kidney IRI through blocking the downstream complement activation initiated by collectin-11 $(9,58)$. Taken together, the AP and LP are the predominant pathways triggering the complement cascade during kidney IRI, while counteracting these two pathways could effectively ameliorate complement activation and the inflammatory response, therefore preserving the integrity of the kidney.

\section{Involvement of Complement Regulators in Kidney IRI}

Complement regulators are also involved in kidney IRI. Mice with genetic deficiency of CD55 and CD59 were more susceptible to IRI (19), while the overexpression of human CD55 and CD59 proteins in mice reduced the complement fragment deposition in the kidney and yielded better renal function (59). Deficiency of Crry, the mouse CD46 homologue, was found to be associated with aggravated IRI outcomes $(18,53)$. However, complement activation is not absolutely without merit in kidney IRI. A recent study has shown that the inhibition of properdin, which stabilizes the $\mathrm{C} 3$ convertase of the AP, led to aggravated renal function and histological changes in the kidney subjected to IRI (24). Deficiency of properdin ameliorated the complement activation during IRI. Meanwhile, it impaired the opsonization effect and the phagocytosis activity of TECs, dampened the clearance of apoptotic cells, and amplified inflammation (24).

\section{Involvement of Complement Receptors in Kidney IRI}

Anaphylatoxin receptors are also involved in the development of kidney IRI. C3aR and C5aR1 are expressed on both infiltrating immune cells and in kidney parenchymal cells, and their expressions were elevated upon IRI $(60,61)$. The inhibition of either receptor reduced the expressions of chemokines and cytokines and decreased the infiltration of inflammatory cells, therefore protecting against kidney injury (61-63). Genetic ablation of these receptors conferred similar results $(42,64)$. Recent evidence has shown that, aside from attracting inflammatory cells such as macrophages and neutrophils (32), the activation of C5aR1 was also associated with cellular senescence within the kidney (65). Analysis of the DNA methylation in C5a-treated TECs showed aberrant methylation of the regions involved in cell cycle, DNA damage, and Wnt signaling pathway. Further experiments confirmed the existence of cell senescence in C5a-treated TECs and in kidney IRI in vivo (65). Also, C5aR1 was found to be expressed on fibroblasts and was involved in fibroblast activation and proliferation after IRI (13). Therefore, anaphylatoxin receptors, especially C5aR1, exerts multifaceted effects during the development of IRI by modulating the activity of a variety of cells. 
Unlike the established pro-inflammatory roles of $\mathrm{C} 3 \mathrm{aR}$ and $\mathrm{C} 5 \mathrm{aR} 1$, the role of $\mathrm{C} 5 \mathrm{aR} 2$ in kidney IRI remains a mystery. C5aR2 was identified as an inactive decoy receptor for C5a when first discovered since it was incapable of coupling $G$ protein and transducing signals. However, growing evidence has raised doubts on this notion. Studies have shown that the deficiency of C5aR2 was associated with a decreased kidney injury upon IRI (45). The reduced expression of myeloperoxidase (MPO) and the decreased activity of neutrophils might account for this protective effect (32). However, controversy still exists. Another study using C5ar2deficient mice failed to show any protective effect against kidney IRI (46). In addition, unlike C5aR1, the expression of C5aR2 in TECs was not elevated upon hypoxia/regeneration treatment (43), questioning the role of $\mathrm{C} 5 \mathrm{aR} 2$ in this scenario. Moreover, the absence of $\mathrm{C} 5 \mathrm{aR} 2$ in a murine intestinal IRI model led to worsened ischemia injury and elevated neutrophil infiltration through augmenting C5a-C5aR1 signaling (66). These controversies might partially be attributed to the fact that the C5ar2-knockout mice used in these experiments were of systemic genetic deficiency. Since C5aR2 is widely expressed on a variety of cell types, the deficiency of $\mathrm{C} 5 \mathrm{aR} 2$ on certain parenchymal cells might blur the effect of C5aR2 on immune cells. Therefore, further exploration is needed to dissect the detailed function of $\mathrm{C} 5 \mathrm{aR} 2$ on specific cell types. These controversial results also indicated that the regulation of $\mathrm{C} 5 \mathrm{aR} 2$ and its downstream effects are more complicated than thought. Future investigations need to establish new animal models with bone marrow chimerism or cell typespecific ablation of C5aR2 and to examine the detailed role of C5aR2 signaling in kidney IRI and in other inflammatory diseases.

\section{Complement Components Interact With Coagulation Factors}

Complement components also interplay with the coagulation cascade during activation. These two processes both belong to the innate immune response and react rapidly upon recognition of pathogen or injury. The complement system could be activated by the coagulation factors at the initiation phase. Factor XII activated the CP, while fibrin and its fragments were found to activate MASPs, the serine proteases of the LP $(67,68)$. Moreover, thrombin and other coagulation factors, such as factors XIa, Xa, and IXa and plasmin, could directly cleave C5 without the presence of complement serine proteases and lead to the formation of MAC $(69,70)$. Instead of producing C5a and $\mathrm{C} 5 \mathrm{~b}$, thrombin cleaved $\mathrm{C} 5$ at a new site and produced $\mathrm{C} 5 \mathrm{a}(\mathrm{T})$ and $\mathrm{C} 5 \mathrm{~b}(\mathrm{~T})$, and the latter formed $\mathrm{C} 5 \mathrm{~b}(\mathrm{~T})-9$ with an even higher cytolytic activity than C5b-9 (71). Besides cleaving complement components directly, coagulation factors could also modulate complement activation through other mechanisms. Proteaseactivated receptors (PARs) are a subfamily of membranebound $\mathrm{G}$ protein-coupled receptors activated by the proteolytic cleavage at their extracellular domain (72). Thrombin cleaved and activated PAR-1, PAR-3, and PAR-4. The activation of PAR1 on dendritic cells led to the elevated expressions of $\mathrm{C} 3$ and complement receptors (73).

On the other hand, the activated complement cascade also modulates the coagulation process. MASP $1 / 2$ of the LP could cleave prothrombin, fibrinogen, and factor XIII into their activated state since the activation of these factors relies on a similar proteolytic mechanism (68). Studies have shown that the formation of $\mathrm{C} 5 \mathrm{a}$ and MAC resulted in the expressions of tissue factors in endothelial cells and in neutrophils, which in turn initiated the extrinsic coagulation pathway (67). C5 was also shown to cleave prothrombin in association with CD14 in a Heme-induced thromboinflammation model (74). In IRI, the release of DAMPs and tissue factors activates the complement and the coagulation cascades. The former lyses injured cells or marks them for phagocytosis, and the latter forms clots in the tubular region. These two processes orchestrated each other at multiple stages, forming positive feedback $(72,75,76)$.

\section{Consequences of Complement Activation in Kidney IRI}

Activation of the complement system upon IRI leads to multiple pathophysiological changes within the kidney. Tubular and endothelial cells are at the front line in contact with complement fragments (1). The assembly of MAC on these cells results in direct cell lysis, which serves as an amplifier for further inflammation. A study has shown that the sublytic MAC treatment in TECs also led to actin reorganization and epithelial-mesenchymal transition, the latter of which was necessary for the development of renal fibrosis after kidney injury (14). The binding of MBL and the following internalization also induced tubular cell death (57). Moreover, complement fragments were associated with elevated NADPH oxidase enzyme activity, which produced excessive reactive oxygen species (ROS) and aggravated kidney IRI (77).

The cleavage of C3 and C5 leads to the formation of anaphylatoxins. The binding of these fragments to the corresponding receptors on kidney parenchymal cells and immune cells results in the production of inflammatory cytokines together with the influx of macrophages and neutrophils, which further amplifies the inflammatory response. Large fragments produced by complement cleavage are deposited in injured cells and mark them for immune cell opsonization and phagocytosis (33). Therefore, inflammation is in the center of complement activation. The initial purpose of complement activation and the subsequent inflammatory response is to create an immune microenvironment for the clearance of injured cells and the subsequent repair process. However, severe and persistent kidney injury leads to uncontrolled inflammation and exceeds the maximum capacity of the repair mechanism, thereby aggravating kidney injury (78).

\section{Complement as a Therapeutic Target of Kidney IRI in Animal Models}

Since complement activation and the subsequent inflammatory response are closely related to kidney IRI, multiple strategies have been developed to counteract this injury by inhibiting complement activation in animal models. These strategies could be summarized into three categories: directly inhibiting the complement cleavage cascade, targeting complement receptors, and modulating complement regulatory proteins. $\mathrm{C} 1-\mathrm{INH}$, also known as the $\mathrm{C} 1$ esterase inhibitor, blocks both the CP and LP by inactivating the 
serine proteases $\mathrm{C} 1$ complex and MASPs. The efficacy of C1-INH in treating kidney IRI has been confirmed in several studies $(79,80)$. In a pig model of kidney autotransplantation, the allograft was subjected to $60 \mathrm{~min}$ of warm ischemia followed by $24 \mathrm{~h}$ of cold ischemia. C1-INH treatment alleviated the kidney injury and improved the long-term graft outcome (79). Earlier studies tried to inhibit the expressions of C3 and C5 using an RNA interference strategy $(50,51)$; however, the clinical significance might be limited due to the lack of targeting efficiency and to other potential side effects. A more recent study has developed a neutralizing anti-C5 antibody, called Ergidina, to solve this problem. This antibody was coupled with the cyclic RGD (Arg-Gly-Asp) peptide, which could deliver the antibody into ischemic endothelial cells (81). The targeting efficiency was confirmed in both an animal kidney IRI model and in a surgically removed human kidney specimen subjected to cold ischemia ex vivo (81). Another strategy focused on the complement regulatory protein $\mathrm{FH}$. The authors developed a fusion protein by conjugating the function domain of $\mathrm{FH}$ with CRIg, which could help deliver the fusion antibody to the complement activation site (46).

\section{INVOLVEMENT OF COMPLEMENT ACTIVATION IN KIDNEY TRANSPLANT DGF}

\section{Complement Activation Contributes to DGF}

Kidney IRI directly contributes to the development of DGF. However, unlike the IRI induced in animal models, during which the injury consisted of only a short period of warm ischemia followed by reperfusion, DGF in the clinical setting is also influenced by a variety of other factors. The primary disease and the physical condition of the donor, the warm ischemia time, the ex vivo storage period, the reperfusion during transplantation, and the subsequent alloreactive immune response could all contribute to the development of DGF, dampening allograft recovery and function. Complement activation occurs in each of these processes (Figure 2). Elevated complement activation has been found in kidney transplant recipients with DGF. Blood samples isolated from the renal vein during transplant reperfusion showed an increased level of soluble C5b-9 (sC5b-9) in the DGF group compared with patients with early graft function (82). Examination of kidney biopsy also revealed an increased deposition of C3d and MAC in DGF patients (46). Studies have shown that the activation of the complement system occurred prior to organ procurement and IRI (83). Transcriptomic analysis of kidney biopsy showed that the complement cascade was activated before circulation cessation and organ retrieval in brain death donors. The same phenomenon was also observed in cardiac death donors, in which the kidney underwent the first warm ischemia period. However, kidney from healthy donors did not have this effect (84). Moreover, assessment of sC5b-9 in venous blood during transplant reperfusion also indicated that $\mathrm{sC} 5 \mathrm{~b}-9$ existed only in kidney from deceased donors, but not in those from living donors (85). Elevated AP activity was also observed in serum from deceased donors compared with their healthy counterparts (86). These reinforced the clinical observation that DGF is more prevalent in allografts from deceased donors. The presence of complement activation in deceased donors prior

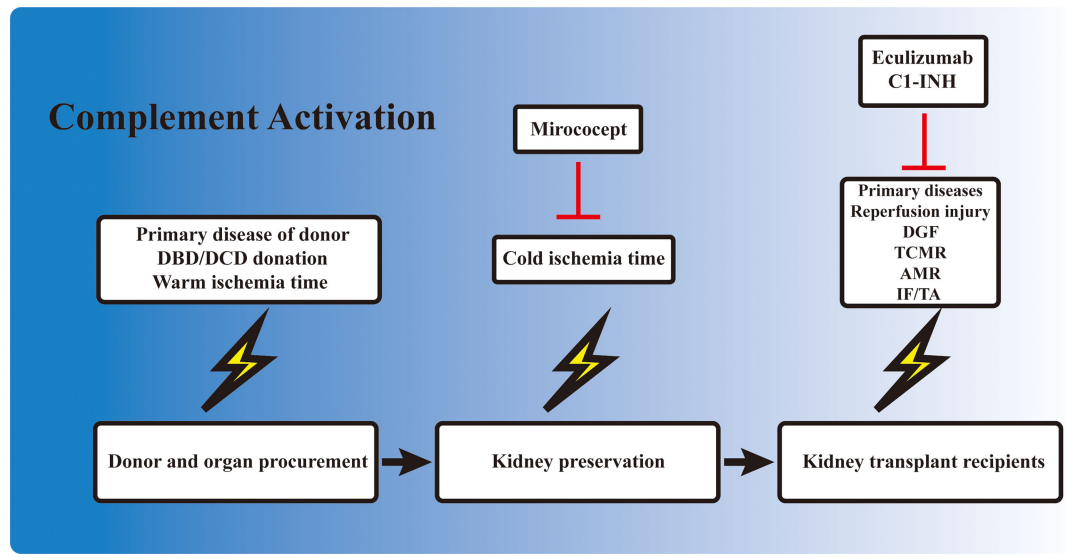

FIGURE 2 | Involvement of complement activation in kidney transplantation. Activation of the complement cascade is involved before organ procurement, during ex vivo preservation, and also in kidney allograft recipients. The complement system is activated in deceased donors due to the unstable hemodynamics and impaired homeostasis. The kidney also undergoes a short warm ischemia period during procurement, which potentially activates the complement system. Ex vivo preservation of the kidney is accompanied with a cold ischemia period, which is also associated with complement gene expression. When the allograft is transplanted into the recipient, the kidney allograft first undergoes a reperfusion injury, and the subsequent delayed graft function (DGF) in certain cases. T-cell- and B-cell-mediated rejection is also activated and regulated by the complement components. Finally, the development of interstitial fibrosis/tubular atrophy (IF/TA), including the activation of fibroblasts, is associated with complement factors. Mirococept has been tested in the EMPIRIKAL trial to reduce ischemia-reperfusion injury (IRI). Clinical trials of eculizumab and C1-INH mainly focused on the reduction of DGF or the prevention/treatment of antibody-mediated rejection (AMR) in kidney transplant recipients. 
toorgan procurement might be attributed to the unstable hemodynamics, impaired homeostasis, and the circulating DAMPs released from injured cells. These results highlighted the importance of the early inhibition of the complement system even before organ procurement, especially in deceased donors.

\section{Complement Factors as Biomarkers to Predict DGF}

The association between complement activation and DGF makes complement fragments the ideal biomarkers for predicting allograft function and long-term outcomes. Studies have shown that the perioperative serum level of sC5b-9 had high sensitivity and specificity in predicting the 1-year allograft outcome (82). Elevated sC5b-9 levels also correlated with the prolonged duration of DGF and worsened graft function (87). In addition, attempting to predict the allograft outcome by simply genotyping specific genes, several other studies were devoted to exploring the association between the polymorphism of certain complement genes and graft function. However, the majority of these studies failed to demonstrate any correlation, which included gene polymorphism studies of the $\mathrm{C} 3, \mathrm{C} 4$, and $\mathrm{MBL}$ pathways $(88,89)$. This could be attributed to the limited sample size of each cohort and the inadequate follow-up period. Moreover, it has been proposed that combination of multiple complement-related gene polymorphisms might be needed to provide sufficient prediction efficiency in allograft outcomes (90).

\section{Ex Vivo Inhibition of Complement Activation to Prevent DGF}

The static cold storage and machine perfusion of kidney allografts provided a perfect platform for ex vivo drug delivery and inhibition of the complement system. Ex vivo drug delivery can avoid the first pass elimination in the liver and other potential side effects. Studies have shown that ex vivo cold storage was associated with the upregulation of certain complement-related genes (91). This demonstrated the necessity of intervention during ex vivo storage to minimize complement activation. Several attempts have been made in this field and have brought some inspiring results. In a rat study, the donor kidneys were treated with either anti-rat monoclonal antibody (mAb) 18A10, a terminal complement pathway inhibitor, or TT30, a selective AP inhibitor, ex vivo at $4^{\circ} \mathrm{C}$ for $28 \mathrm{~h}$ before transplanting into syngeneic rat (92). Graft survival in both treatment groups improved compared with the control ones, and the 18A10-treated grafts presented better outcomes (92). This demonstrated the feasibility and efficacy of inhibiting complement activation ex vivo. Mirococept is a complement inhibitor derived from human CR1. It was shown to counteract IRI-induced inflammatory response in animal studies. Therefore, it was further tested in a clinical trial to reduce DGF incidence. EMPIRIKAL is a multicenter double-blind randomized casecontrol study that applied Mirococept to reduce DGF incidence in cadaveric kidney transplantation. Mirococept $(10 \mathrm{mg})$ was given ex vivo during allograft preservation, and the primary endpoint was the incidence of DGF (93). However, no superiority was seen in the Mirococept treatment group; hence, the study was stopped. Further exploration in a porcine study revealed that the failure of the EMPIRIKAL study was due to insufficient Mirococept exposure. The optimal dosage was later determined to be $80 \mathrm{mg}$ for pig kidney experiment, equivalent to $120 \mathrm{mg}$ in a human setting, with efficient therapeutic effects and no obvious side effects (94). Further investigation is needed to explore the efficacy of ex vivo Mirococept delivery in kidney transplant. Other attempts in this field included perfusing and preserving the allograft in solution containing certain siRNA cocktail (95) or constructing targeted binding neutralizing antibody (81).

\section{ROLE OF COMPLEMENT IN T-CELL- MEDIATED REJECTION}

TCMR remains a major threat to graft survival after kidney transplantation. The key mechanism of TCMR is the priming and activation of $\mathrm{T}$ cells, including $\mathrm{T}$ helper ( $\mathrm{Th}$ ) cells and cytotoxic T cells (cytotoxic T lymphocytes, CTLs). The former is responsible for releasing cytokines and forms an inflammatory microenvironment, while the latter kills target cells with perforin, granzymes, and Fas ligands. The complement has long been deemed as part of the innate immunity, which is separated from the adaptive immune response. However, recent findings have indicated that the complement plays important roles in the regulation of $\mathrm{T}$-cell activity, either by modulating antigenpresenting cells (APCs) or by directly influencing $\mathrm{T}$ cells (Figure 3).

\section{Regulation of Complement Components in Dendritic Cells}

Dendritic cells (DCs) are a major type of APCs and are responsible for T-cell activation in response to stimuli (96). Capture of antigen, together with other stimulatory signals such as activation of the Toll-like receptors (TLRs), leads to the maturation of DCs and their migration to the secondary lymphoid tissue, where they present the antigen and costimulatory signals to elicit T-cell response. DCs rely on a variety of complement components, receptors, and regulatory proteins to fulfill their roles $(97,98)$. DCs with $C 3$ deficiency failed to stimulate $\mathrm{T}$-cell response properly upon alloantigen treatment and impaired the Th1/Th2 balance, with reduced Th1 response and elevated Th2 activity (99). Moreover, deficiency of C3 in DCs ameliorated the allograft rejection in a murine skin transplantation model (99). Further analysis revealed that C3deficient DCs expressed less major histocompatibility complex (MHC) II, B7-2, and IL-12, which were necessary for inducing proper Th1 response (100). Genetic or pharmacological ablation of $\mathrm{C} 3 \mathrm{aR}$ also elicited defective $\mathrm{T}$-cell activation, suggesting that $\mathrm{C} 3 \mathrm{a}-\mathrm{C} 3 \mathrm{aR}$ signaling was necessary for the antigen presentation activity of DCs (101). Studies have shown that the defective complement FB in DCs also led to reduced T-cell priming and activation, indicating the involvement of the AP in this setting (7, 101). On the contrary, the downregulation of DAF in DCs increased the expressions of $\mathrm{C} 3 \mathrm{a}$ and $\mathrm{C} 5 \mathrm{a}$ and augmented the 


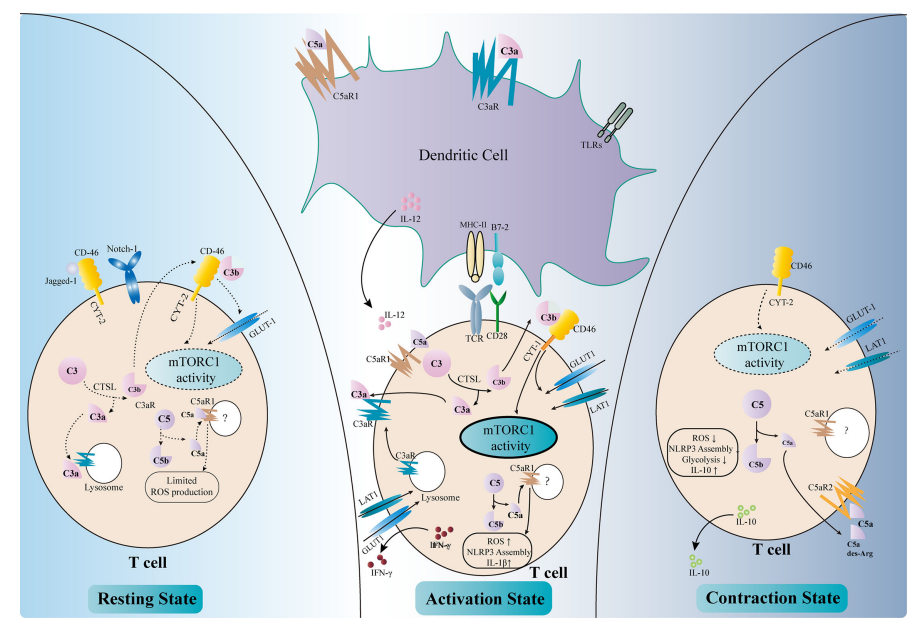

FIGURE 3 | Regulation of T-cell activity by complement components. Complement factors modulate T-cell activation either directly or indirectly (middle part of the figure). C3aR and C5aR1 are expressed on dendritic cells (DCs). The binding of C3a and C5a, together with Toll-like receptor (TLR) signals, upregulates the expressions of MHC II, B7-2, and IL-12 and enhances the antigen presentation activity of DCs. The intracellular complement system directly regulates T-cell activity. The activation of T-cell receptors (TCRs) and co-stimulatory receptors leads to the intracellular cleavage of C3 by cathepsin $\mathrm{L}$ (CTSL). C3a and the C3aR transported from the lysosome to the cell surface reinforce C3a-C3aR signaling in T cells. C3b binds to CD46-CYT-1 and upregulates the nutrient transporters such as GLUT1 and LAT1. The activation of CD46-CYT-1 also enhances the activity of mTORC1, which modulates the cellular metabolism activity and promotes Th1 response. Intracellular $\mathrm{C} 5 \mathrm{a}-\mathrm{C} 5 \mathrm{aR} 1$ signaling increases the reactive oxygen species (ROS) level in the mitochondria, therefore promoting the assembly of the NLRP3 inflammasome and the production of IL-1 $\beta$. These changes lead to the production of IFN- $\gamma$ necessary for Th1 response. Complement also regulates Tcell homeostasis (left part of the figure). In resting T cells, tonic intracellular cleavage of C3 by CTSL produces C3a and C3b. C3a binds to C3aR on lysosomes, while C3b binds to CD46-CYT-2 on the cell surface. The latter sustains a limited mTORC1 activity and the expression of GLUT-1. Intracellular C5a-C5aR1 signaling also produces limited amounts of ROS necessary for T-cell survival. In addition, CD46 could bind to Jagged-1, therefore inhibiting the Notch-1 signaling required for T-cell activation. In the contraction phase after T-cell activation (right part of the figure), CD46 adopts the CYT-2 isoform, identical with the resting state. This leads to decreased mTORC1 activity and declined expressions of the nutrient transporters. Instead of binding to intracellular C5aR1, C5a and its derivative C5a-desArg are secreted to the extracellular space and bind to C5aR2 on the cell surface, therefore inhibiting intracellular C5a-C5aR1 signaling. These changes result in decreased ROS production and NLRP3 activity, as well as elevated IL-10 level.

T-cell response (102). Recent findings have shown that C5aC5aR1 signaling was also involved in DC-induced T-cell priming and activation $(10,103)$. The engagement of these anaphylatoxins to their receptors drove the expressions of MHC molecules, co-stimulatory signals, cytokines, and growth factors, which were indispensable for T-cell activation and kidney allograft rejection (104). Apart from activating $\mathrm{T}$ cells, complement components also negatively regulate the immune response by modulating the functions of DCs. C1q, the first complement factor of the $\mathrm{CP}$, was found to be associated with the differentiation of DCs and the DC-induced immune tolerance (105-107). In addition, dexamethasone treatment upregulated the expression of the complement immunoglobulin receptor (CRIg) on human monocyte-derived DCs, which was necessary for the steroid-induced negative regulation of Th1 response (108).

\section{Direct Effects of Complement Components in T-Cell Regulation}

Anaphylatoxin receptors are also expressed on $\mathrm{T}$ cells and are involved during their activation. The ligation of C3aR and C5aR1 on the surface of $\mathrm{T}$ cells orchestrates the inflammatory response and leads to the production of IL-12 necessary for Th1 activation (102, 109). Moreover, these complement receptors also exist intracellularly within $\mathrm{T}$ cells and regulate $\mathrm{T}$-cell responses (17). Stimulation of T-cell receptor (TCR) and the co-stimulatory receptor CD28 augments the intracellular cleavage of C3 by cathepsin L (CTSL) (110). The C3a fragments are transported to the cell membrane and bind to their corresponding receptors to further amplify the activation signal of $\mathrm{T}$ cells. $\mathrm{C} 3 \mathrm{aR}$ expressed on lysosome are also transported to the cell membrane to reinforce $\mathrm{C} 3 \mathrm{a}-\mathrm{C} 3 \mathrm{aR}$ signaling upon activation (111). Intracellular cleaved C3b could bind to CD46, a membrane-bound complement regulatory protein. CD46 was originally defined as a cofactor for FI-mediated cleavage of $\mathrm{C} 3 \mathrm{~b}$ and C4b. However, the role of CD46 in this context is far beyond a negative regulator of the complement cascade. Activated CD46 signaling promotes the alternative splicing of the CYT-1 isoform, which in turn increases the expression of the glucose transporter GLUT1 and the amino acid transporter LAT1 (112). This results in a metabolic switch toward glycolysis in T cells, which provides sufficient energy and the metabolic substrates necessary for Th1 response. CD46 also upregulates the expression of the late endosomal lysosomal adaptor, MAPK and mTOR Activator 5 (LAMTOR5), which is associated with the sensing of amino acids by mTORC1 (112). Moreover, the CD46 signals increase the nutrient influx and fatty acid oxidation activity in CD8 ${ }^{+}$CTLs, augmenting their cytolytic activity (113). Taken together, the 
increased intracellular cleavage of $\mathrm{C} 3$ and the activated CD46 signals result in elevated glycolysis and oxidative phosphorylation, which are essential for Th1 response and CTL activation. In accordance with these results, elevated expressions of the CD46 transcripts have been observed in the tubulointerstitial area of kidney allografts with chronic active antibody-mediated rejection (AMR), in which the Th1 response is required (114). A similar intracellular C5a-C5aR1 signaling also exists in T cells and could be amplified by CD46 signaling. Activation of intracellular C5aR1 augments ROS production from the mitochondria and promotes the assembly of the NLRP3 inflammasome (115). This further promotes the production of cleaved IL- $1 \beta$ and IFN- $\gamma$, which are vital for Th1 response. However, the detailed mechanisms of how C5 is cleaved intracellularly and how the cleaved fragments interact with intracellular C5aR1 remain unclear (116).

Apart from $\mathrm{T}$-cell activation and Th1 polarization, complement components also participate in maintaining T-cell homeostasis (Figure 3). The intracellular tonic cleavage of C3 by CTSL generates $\mathrm{C} 3 \mathrm{a}$, which interacts with $\mathrm{C} 3 \mathrm{aR}$ on lysosomes and results in a minor but sufficient mTOR signaling and glycolysis activity for T-cell survival (111). CD46 is alternatively spliced into the CYT- 2 isoform in resting $\mathrm{T}$ cells and maintains the expressions of GLUT1 and Bcl-2 to avoid apoptosis (104). In addition, CD46 has been shown to bind Jagged-1, the Notch-1 ligand, therefore blocking the Notch signaling essential for T-cell activation (17). A low level of intracellular $\mathrm{C} 5 \mathrm{a}-\mathrm{C} 5 \mathrm{aR} 1$ signaling has also been proposed to maintain T-cell homeostasis by producing limited amounts of ROS. However, the detailed mechanism remains unclear (17).

Complement components also regulate the "contraction" phase of Th1 response to resolve inflammation (Figure 3). Again, CD46 plays a major role in this scenario (117). CD46 turns back to the CYT-2 isoform, in accordance with the resting phase, and downregulates the expressions of GLUT1 and LAT1, therefore decreasing glycolysis and mTOR activity (16). Moreover, the anaphylatoxin C5a and its fragment C5a-desArg could be secreted to the extracellular space and suppress the ROS activity by binding to cell surface C5aR2 (16). These effects lead to the production of IL-10, which resolves the proinflammatory response.

Taken together, the intracellular complement components, especially the anaphylatoxin receptors and CD46 signaling, dictate T-cell homeostasis, activation, and contraction. These factors regulate the $\mathrm{T}$-cell activity mainly by modulating the cellular metabolic activity. However, evidence of intracellular complement activation is still limited in the field of organ transplantation, which might be partially attributed to the versatile function of CD46. Since CD46 also acts as a cofactor of FI-mediated cleavage of $\mathrm{C} 3 \mathrm{~b}$, certain CD46 polymorphism was found to be associated with reduced acute rejection and better allograft survival in kidney transplant recipients (118). Transgenic expression of human CD46 was also a promising strategy to attenuate hyperacute rejection in xenograft experiments $(119,120)$. Therefore, further investigations in this field need to focus on the versatile function of CD46, and targeted intervention of intracellular complement signaling might be a promising therapy to attenuate $\mathrm{T}$-cell activation and alleviate allograft rejection.

\section{ROLE OF COMPLEMENT IN ANTIBODY- MEDIATED REJECTION}

AMR remains the leading cause of graft loss after kidney transplantation, and it lacks efficient treatment. Knowledge of complement activation in AMR arose from the findings of complement-dependent cytotoxicity (CDC) (121) and the deposition of C4d in peritubular capillaries in kidney allografts (122). Complement components regulate the development of AMR and also participate in AMR-mediated allograft injury.

The complement receptor CR2 participates in B-cellmediated humoral response. The binding of C3d-opsonized antigen to CR2 on B cells promotes B-cell activation and antibody production by lowering its activation threshold (123). CR2 expressed on follicular DCs retains C3d-opsonized antigens within the germinal center, which is essential for memory B-cell maintenance (104). In addition, CR2 signaling is associated with the negative selection of self-reactive $B$ cells and the positive selection of B-1 cells (17). The intracellular complement system, which is vital for T-cell homeostasis and activation, is also observed in B cells (17). However, the involvement of the intracellular complement activation in B-cell activation and antibody production awaits further investigation.

Complement is also associated with AMR-mediated allograft injury. Donor-specific antibodies (DSAs), including anti-ABO and anti-HLA antibodies, bind to endothelial cells during AMR and enable the engagement of $\mathrm{C} 1 \mathrm{q}$, which initiates the $\mathrm{CP}$. Activation of the complement cascade and the assembly of MAC lead to endothelial cell lysis and dampen the vasculature integrity of allografts, a process known as CDC. MAC also initiates the pro-inflammatory signaling in endothelial cells (10). Together with the anaphylatoxins C3a and C5a produced during the cleavage cascade, it reinforces this inflammatory microenvironment (124). In addition, activation of the complement system promotes the adaptive immune response. Studies have shown that the antibody-induced MAC on endothelial cells enhanced the alloreactive T-cell response and increased the production of IFN- $\gamma$, which was essential for Th1 polarization and further amplified the humoral response (124). In addition, the assembly of MAC also leads to the production of tissue factors in endothelial cells, which could initiate the coagulation cascade (125). This partially explains the presence of thrombotic microangiopathy in certain AMR cases.

Deposition of C4d has been deemed as one of the diagnostic criteria of AMR. However, emerging pieces of evidence are questioning the clinical significance of C4d in this scenario. This arose from the observation that kidney transplant recipients without AMR could also present C4d deposition in allograft biopsy, while the absence of $\mathrm{C} 4 \mathrm{~d}$ was not sufficient to exclude AMR $(126,127)$. A retrospective study found that, 
although C4d-positive AMR patients presented clinical manifestations earlier and more frequently when compared with C4d-negative AMR patients, the 1- and 2-year graft survival rates post-AMR diagnosis were similar between the two cohorts (127). In addition, the clinical characteristics and the risk of graft loss were similar between the two cohorts despite the absence of C4d (127). In fact, in the current Banff criteria, $\mathrm{C} 4 \mathrm{~d}$ is no longer the prerequisite for AMR diagnosis, and " $\mathrm{C} 4 \mathrm{~d}$ staining without evidence of rejection" has been included as a subtype of antibody-mediated changes (128). The declining importance of C4d gives way to the DSA assay measuring complement binding activity (129). C3d-binding DSAs in AMR patients were associated with increased graft loss, deteriorated allograft function, and higher DSA mean fluorescence intensity (MFI) (130). Another study in nonsensitized pediatric kidney recipients reinforced the value of C3d-binding DSAs in predicting long-term graft survival (131). DSAs could be further classified as de novo DSAs (dnDSAs) and preformed DSAs (pDSAs). The former are developed after transplantation and the latter exist in the recipients before transplantation. Positive C3d-binding dnDSAs were found to be associated with the presence of $\operatorname{AMR}(132,133)$. A study on pDSAs indicated that half of the C3d-negative pDSAs disappeared after transplantation, while all C3d-binding pDSAs persisted despite desensitization (134). Moreover, C3d-binding pDSAs were associated with a higher risk of developing AMR (134). However, the role of C1q-binding DSAs has been controversial. Some studies showed similar or minor predictive value of C1q-binding with C3d-binding DSAs (130-132), while some highlighted that the C1q-binding capacity could only reflect the MFI of DSAs instead of predicting allograft prognosis (135).

Taken together, the activation of the complement system participates in the regulation of humoral response and plays roles in antibody-mediated graft injury. Moreover, complement fragment-binding DSAs seem a promising feature for predicting AMR and graft survival. Therefore, complement could serve as a potential therapeutic target of AMR. Several clinical trials using eculizumab or C1-INH in the prophylaxis or treatment of AMR have shown encouraging results and might provide additional choice for AMR treatment in the future (Tables 2 and 3 ).

\section{COMPLEMENT ACTIVATION IN CHRONIC ALLOGRAFT INJURY}

Chronic allograft nephropathy, now known as interstitial fibrosis/tubular atrophy (IF/TA), is the consequence of maladaptive repair after allograft injury. A variety of causes, including but not limited to IRI, drug toxicity, infection, and rejection, could all lead to the progression of IF/TA (78). The development of IF/TA usually involves the presence of tubular injury, unresolved inflammation, and microvasculature refraction (78). All these pathological changes lead to myofibroblast activation and the production of extracellular matrix, which forms a scar in the kidney and causes gradual loss of allograft function. Activation of the complement system leads to a direct cytolytic effect on tubular and endothelial cells, which impairs tubular function and the vasculature integrity. Anaphylatoxins attract immune cell infiltration, forming an inflammatory microenvironment that favors the development of IF/TA. Abundant evidence has confirmed the role of complement in the development of renal fibrosis in animal models $(12,13,163)$. However, the majority of these studies only focused on the fibrotic phenotype of the kidney, while evidence for the regulation of fibroblast activity by complement components is still limited. Peng et al. demonstrated the presence of $\mathrm{C} 5 \mathrm{aR} 1$ on resting primary kidney fibroblast and the elevation of its expression upon hypoxia (13). Moreover, C5a treatment led to increased proliferation and mesenchymal activation in resting fibroblast (13). Scattered pieces of evidence in other fields also reinforce the role of complement components in the regulation of fibroblast activity. Earlier studies showed that C5a-C5aR2 signaling was required for fibroblast functions (164). In a diabetic kidney disease model, $\mathrm{C} 3 \mathrm{aR}$ and $\mathrm{C} 5 \mathrm{aR} 1$ activation induced the mesenchymal transition in endothelial cells, a process closely related to fibroblast activation (165). Treatment of human primary lung fibroblasts with $\mathrm{C} 3 \mathrm{a}$ and $\mathrm{C} 5 \mathrm{a}$ stimulated their mesenchymal activation and the production of extracellular matrix (166). Studies in pulp fibroblasts also showed that anaphylatoxin receptor signaling was involved in the activation of fibroblasts after injury (167-169). CD10 ${ }^{+} \mathrm{C} 5 \mathrm{aR} 2^{+}$cancerassociated fibroblasts were associated with the inflammatory microenvironment favoring tumor stemness, which was also required for the development of IF/TA $(170,171)$. Recent research in arthritis has highlighted the role of intracellular $\mathrm{C} 3 \mathrm{aR}$ signaling in synovial fibroblasts. The activation of $\mathrm{C} 3 \mathrm{aR}$ led to increased metabolic activity in these cells, which was mediated by the elevated mTOR signaling and HIF- $1 \alpha$ production. The NLRP3 inflammasome was also induced upon $\mathrm{C} 3 \mathrm{aR}$ activation, enhancing local inflammation and aggravating arthritis (172). This is in accordance with the findings of the intracellular complement modulation in T cells. Since fibroblasts are a highly heterogenic cell population, the detailed involvement and the mechanism of complement activation in fibroblast activity urge further investigations.

\section{TARGETING COMPLEMENT ACTIVATION IN KIDNEY TRANSPLANT RECIPIENTS}

Apart from intervention before and during organ procurement, targeting the complement system in allograft recipients is also a promising strategy. Several complement inhibitors were developed and underwent clinical trials in kidney transplant recipients, among which eculizumab and the $\mathrm{C} 1$ esterase inhibitor are the most promising ones. Eculizumab is a recombinant humanized hybrid IgG2/IgG4 monoclonal antibody that targets C5, the key molecule of complement activation. The binding of eculizumab to $\mathrm{C} 5$ prevents its cleavage by serine proteases, therefore inhibiting the production of C5a and the assembly of MAC (125). Eculizumab has 
TABLE 2 | Clinical trials of eculizumab in kidney transplantation.

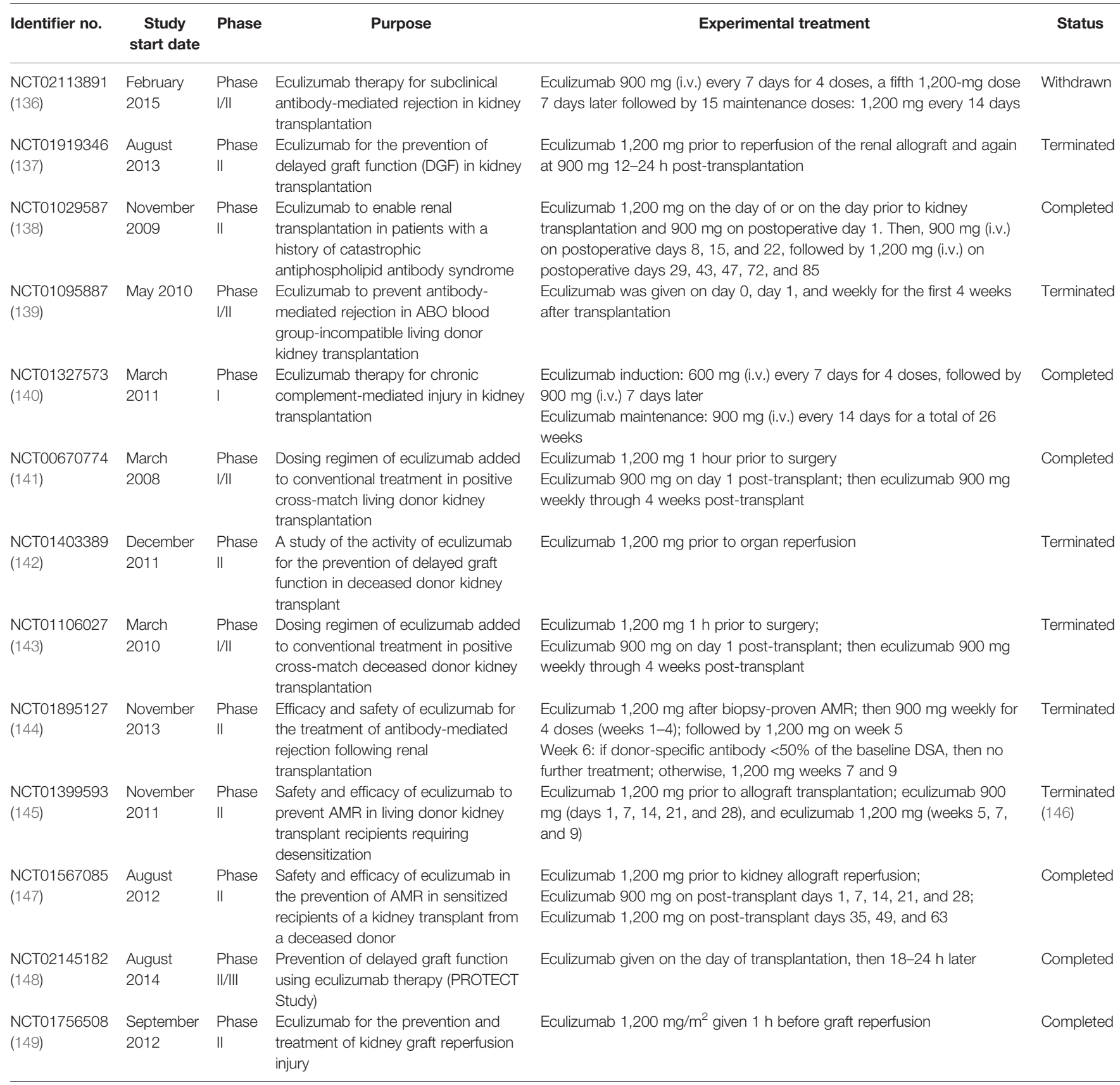

AMR, antibody-mediated rejection; DSA, donor-specific antibody.

been approved for the treatment patients with paroxysmal nocturnal hemoglobinuria $(\mathrm{PNH})$ and atypical hemolytic uremic syndrome (aHUS), in which aberrant activation of the complement system is involved in the disease progression. Studies have shown that the prophylactic treatment of eculizumab enabled successful kidney transplantation in patients with aHUS and was efficient for improving aHUS recurrence after transplantation $(173,174)$. Eculizumab treatment was also beneficial for successful renal transplantation in patients with antiphospholipid antibody syndrome or C3 glomerulopathy (175-177). Eculizumab treatment has been suggested for the prevention or treatment of AMR in several clinical trials (Table 2). A recent single-arm trial examining the safety and efficacy of eculizumab in preventing AMR in sensitized recipients (NCT01567085) has shown encouraging outcomes. However, controversy in this field still exists. NCT01895127, a study that evaluated the efficacy of eculizumab treatment in kidney transplant recipients with biopsy-proven AMR, failed to demonstrate the superiority of eculizumab compared with standard plasmapheresis and immunoglobin treatment. These controversies might be ascribed to the small study cohort and the 
TABLE 3 | Clinical trials of $\mathrm{C} 1-\mathrm{INH}$ in kidney transplantation.

\begin{tabular}{|c|c|c|c|c|c|}
\hline Identifier no. & $\begin{array}{l}\text { Study } \\
\text { start date }\end{array}$ & Phase & Purpose & Experimental treatment & Status \\
\hline $\begin{array}{l}\text { NCT01035593 } \\
(150)\end{array}$ & $\begin{array}{l}\text { December } \\
2010\end{array}$ & $\begin{array}{l}\text { Phase } \\
\|\end{array}$ & $\begin{array}{l}\text { Recombinant human } \mathrm{C} 1 \text { inhibitor for the treatment of early } \mathrm{AMR} \text { in } \\
\text { renal transplantation }\end{array}$ & $\begin{array}{l}\text { Plasmapheresis }+100 \mathrm{mg} / \mathrm{kg} \text { IVIG every } \\
\text { other day } \times 5 \text { treatments plus rhC } 1 \mathrm{lnh} 100 \\
\mathrm{U} / \mathrm{kg} \text { (i.v.) daily } \times 7 \text { consecutive days }\end{array}$ & Withdrawn \\
\hline $\begin{array}{l}\text { NCT01134510 } \\
(151,152)\end{array}$ & $\begin{array}{l}\text { August } \\
2011\end{array}$ & $\begin{array}{l}\text { Phase } \\
|/| l\end{array}$ & $\begin{array}{l}\text { Prevent complement-dependent, AMR post-transplant in highly HLA- } \\
\text { sensitized patients }\end{array}$ & $\begin{array}{l}\text { C1 esterase inhibitor } 20 \mathrm{U} / \mathrm{kg} \text { twice weekly } \\
\times 4 \text { weeks }\end{array}$ & Completed \\
\hline $\begin{array}{l}\text { NCT02134314 } \\
(153)\end{array}$ & May 2014 & $\begin{array}{l}\text { Phase } \\
|/| \mid\end{array}$ & $\begin{array}{l}\text { C1INH inhibitor preoperative and post-kidney transplant to prevent } \\
\text { DGF and IRI }\end{array}$ & $\begin{array}{l}\mathrm{C} 1 \text { esterase inhibitor } 50 \mathrm{U} / \mathrm{kg} \text { on day of } \\
\text { transplant and another dose at } 24 \mathrm{~h} \\
\text { postoperatively }\end{array}$ & Completed \\
\hline $\begin{array}{l}\text { NCT02936479 } \\
(154)\end{array}$ & $\begin{array}{l}\text { October } \\
2016\end{array}$ & $\begin{array}{l}\text { Phase } \\
\text { ॥ }\end{array}$ & $\begin{array}{l}\mathrm{C} 1 \text { inhibitor }(\mathrm{INH}) \text { for refractory antibody-mediated renal allograft } \\
\text { rejection }\end{array}$ & C1-INH (Berinert) & Completed \\
\hline $\begin{array}{l}\text { NCT03221842 } \\
(155)\end{array}$ & $\begin{array}{l}\text { November } \\
2017\end{array}$ & $\begin{array}{l}\text { Phase } \\
\text { III }\end{array}$ & $\begin{array}{l}\mathrm{C} 1 \text { esterase inhibitor as add-on to standard of care for the treatment } \\
\text { of refractory AMR in adult renal transplant recipients }\end{array}$ & C1 esterase inhibitor & $\begin{array}{l}\text { Terminated } \\
(156)\end{array}$ \\
\hline $\begin{array}{l}\text { NCT02547220 } \\
(157)\end{array}$ & May 2016 & $\begin{array}{l}\text { Phase } \\
\text { III }\end{array}$ & Treatment of acute AMR in participants with kidney transplant & $\begin{array}{l}\text { CINRYZE } 5,000 \cup \text { on day } 1 \text { and } 2,500 \cup \\
\text { on days } 3,5,7,9,11 \text {, and } 13\end{array}$ & Terminated \\
\hline $\begin{array}{l}\text { NCT01147302 } \\
(158)\end{array}$ & $\begin{array}{l}\text { August } \\
2011\end{array}$ & $\begin{array}{l}\text { Phase } \\
\text { ॥ }\end{array}$ & Use of the C1 esterase inhibitor (human) in patients with acute AMR & $\begin{array}{l}\text { C1 esterase inhibitor } 5,000 \cup \text { (not to } \\
\text { exceed } 100 \mathrm{U} / \mathrm{kg} \text { ) on day } 1 \text {, followed by } \\
2,500 \cup \text { (not to exceed } 50 \cup / \mathrm{kg} \text {, i.v.) on } \\
\text { days } 3,5,7,9,11 \text {, and } 13\end{array}$ & $\begin{array}{l}\text { Completed } \\
\text { (159) }\end{array}$ \\
\hline $\begin{array}{l}\text { NCT04696146 } \\
(160)\end{array}$ & $\begin{array}{l}\text { March } \\
2021\end{array}$ & $\begin{array}{l}\text { Phase } \\
|/| \mid\end{array}$ & $\begin{array}{l}\text { Assessing the safety and efficacy of preoperative renal allograft } \\
\left.\left.\text { infusions of } \mathrm{C} 1 \text { inhibitor (Berinert }{ }^{\circledR}\right) \text { (human, } \mathrm{C} 1 \mathrm{INH}\right) \text { vs. placebo } \\
\text { administration in recipients of a renal allograft from deceased high-risk } \\
\text { donors and its impact on DGF and IRI }\end{array}$ & Berinert $500 \cup$ & Recruiting \\
\hline $\begin{array}{l}\text { NCT03791476 } \\
(161)\end{array}$ & June 2019 & $\begin{array}{l}\text { Phase } \\
\text { I }\end{array}$ & $\begin{array}{l}\text { RUCONEST }{ }^{\circledR} \text { as a therapeutic strategy to reduce the incidence of } \\
\text { DGF }\end{array}$ & $\begin{array}{l}\text { rhC1INH } 100 \mathrm{U} / \mathrm{kg} \text { intraoperatively, } \\
\text { followed by } 50 \mathrm{U} / \mathrm{kg} \text { every } 12 \mathrm{~h} \times 2=\text { total } \\
\text { of } 3 \text { doses }(200 \mathrm{U} / \mathrm{kg})\end{array}$ & Recruiting \\
\hline $\begin{array}{l}\text { NCT02435732 } \\
(162)\end{array}$ & $\begin{array}{l}\text { December } \\
2020\end{array}$ & $\begin{array}{l}\text { Phase } \\
\text { I }\end{array}$ & $\begin{array}{l}\text { CINRYZE as a donor pretreatment strategy in kidney recipients of } \\
\mathrm{KDPI}>60 \%\end{array}$ & CINRYZE 200 U/kg (i.v.) single dose & $\begin{array}{l}\text { Not yet } \\
\text { recruiting }\end{array}$ \\
\hline
\end{tabular}

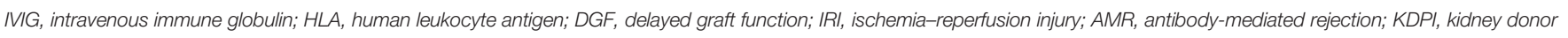
profile index.

insufficient eculizumab exposure in these studies. Several clinical trials in this field have been terminated for poor enrollment, or were conducted in a small cohort, limiting the confidence in these trials. Moreover, the combination of eculizumab with the current standard therapy might provide better clinical outcomes. Eculizumab has also been tested to prevent IRI or DGF in kidney allograft recipients. Disappointingly, a recent published result has shown that the DGF incidence and the early and late posttransplant graft functions were similar between the eculizumab-treated group and the control group (178).

$\mathrm{C} 1-\mathrm{INH}$, an endogenous complement regulatory protein, is also extensively studied in kidney transplantation recipients. C1INH binds to and inactivates the initial serine proteases of the complement cascade, including $\mathrm{C} 1 \mathrm{r}, \mathrm{C} 1 \mathrm{~s}$, and MASPs. Compared with eculizumab, which targets the cleavage of $\mathrm{C} 5$, C1-INH inhibits both the CP and LP at the initiation stage, therefore also eliminating the production of the $\mathrm{C} 3$ and $\mathrm{C} 4$ fragments (179). C1-INH was mostly given perioperatively to protect against IRI and DGF in animal studies and clinical trials (Table 3). A recent non-human primate kidney transplantation study has suggested that treatment of C1-INH in DBD (donation after brain death) donors prevented the development of DGF and improved allograft function (180). A randomized clinical trial using two doses of C1-INH perioperatively also showed encouraging outcomes (181). In brief, 70 kidney recipients were equally randomized to either the $\mathrm{C} 1$-INH treatment group or the control group. $\mathrm{C} 1-\mathrm{INH}$ was given at $50 \mathrm{U} / \mathrm{kg}$ twice. The first dosage was given intraoperatively and the second at $24 \mathrm{~h}$ postoperation. Although the incidence rates of DGF were similar between the two groups, $\mathrm{C} 1-\mathrm{INH}$ treatment led to fewer dialysis session 2-4 weeks after transplantation. The C1-INH treatment group also presented better renal function 1 year posttransplantation compared with the control counterpart (181). Follow-up of the same study revealed that $\mathrm{C} 1-\mathrm{INH}$ treatment decreased allograft loss and improved the estimated glomerular filtration rate (eGFR) even 3 years after transplantation (182). Several upcoming clinical trials evaluating the efficacy of C1-INH in improving DGF are underway and might provide further evidence for the use of $\mathrm{C} 1-\mathrm{INH}$ in kidney transplantation (Table 3). C1-INH was also used to prevent or treat AMR in kidney transplant recipients $(23,151,183)$. A double-blind randomized trial evaluated the use of $\mathrm{C} 1-\mathrm{INH}$ together with standard therapy in patients with AMR (NCT01147302) (159). Treatment with C1-INH yielded a trend toward sustained improvement of allograft function. In addition, C1INH decreased the possibility of developing transplant glomerulopathy compared with the control group (159). In all, the results from recent clinical trials demonstrated that $\mathrm{C} 1-\mathrm{INH}$ might be a feasible treatment for patients with AMR.

Apart from eculizumab and $\mathrm{C} 1-\mathrm{INH}$, several other complement inhibitors have been developed and have undergone clinical trials for the treatment of $\mathrm{PNH}$ and aHUS. Multiple monoclonal antibodies, such as crovalimab, pozelimab, tesidolumab, and ravulizumab, inhibit complement activation 
through targeting C5 (184-187). These antibodies, similarly to the previously mentioned eculizumab, bind to C5 and prevent the downstream activation of the complement cascade. Ravulizumab, also known as Ultomiris, has already been approved to for the treatment of PNH and aHUS in the USA (188). Nomacopan, formerly known as Coversin, is a small protein that also prevents the cleavage of $\mathrm{C} 5$ by the $\mathrm{C} 5$ convertase (189). Cemdisiran represents another strategy that suppresses the liver-produced C5 with RNA interference (190). Despite that the majority of these complement inhibitors target C5, pegcetacoplan is the first and only targeted C3 therapy for the treatment of PNH (191). Pegcetacoplan is a PEGylated peptide that binds to $\mathrm{C} 3$ and its fragment $\mathrm{C} 3 \mathrm{~b}$, eliminating both the cleavage of $\mathrm{C} 3$ and the opsonization effect of $\mathrm{C} 3 \mathrm{~b}$ (191). A recent study has suggested that pegcetacoplan showed superior therapeutic effect than eculizumab in the treatment of PNH (192). This was probably attributed to the early inhibition of the complement cascade by pegcetacoplan. Several orally administered complement inhibitors have also been developed. Vemricopan and danicopan inhibit FD in the AP (193), while iptacopan targets FB (194). In addition, avacopan, a selective C5aR inhibitor, has been approved for the treatment of antineutrophil cytoplasmic antibody (ANCA)-associated vasculitis and has been tested in patients with aHUS (195). Future investigations of these complement inhibitors in kidney transplant recipients might provide additional choices for the prevention and treatment of various complications and improve allograft outcomes.

\section{CONCLUSION AND FUTURE PERSPECTIVES}

Complement components are widely expressed in kidney parenchymal cells and in immune cells. Activation of the

\section{REFERENCES}

1. Franzin R, Stasi A, Fiorentino M, Stallone G, Cantaluppi V, Gesualdo L, et al. Inflammaging and Complement System: A Link Between Acute Kidney Injury and Chronic Graft Damage. Front Immunol (2020) 11:734. doi: 10.3389/ fimmu.2020.00734

2. Reis ES, Mastellos DC, Ricklin D, Mantovani A, Lambris JD. Complement in Cancer: Untangling an Intricate Relationship. Nat Rev Immunol (2018) 18 (1):5-18. doi: 10.1038/nri.2017.97

3. Nauser CL, Farrar CA, Sacks SH. Complement Recognition Pathways in Renal Transplantation. J Am Soc Nephrol JASN (2017) 28(9):2571-8. doi: 10.1681/ASN. 2017010079

4. Kolev M, Markiewski MM. Targeting Complement-Mediated Immunoregulation for Cancer Immunotherapy. Semin Immunol (2018) 37:85-97. doi: 10.1016/j.smim.2018.02.003

5. Mathern DR, Heeger PS. Molecules Great and Small: The Complement System. Clin J Am Soc Nephrol (2015) 10(9):1636-50. doi: 10.2215/CJN.06230614

6. Roumenina LT, Daugan MV, Petitprez F, Sautes-Fridman C, Fridman WH. Context-Dependent Roles of Complement in Cancer. Nat Rev Cancer (2019) 19 (12):698-715. doi: 10.1038/s41568-019-0210-0

7. Casiraghi F, Azzollini N, Todeschini M, Fiori S, Cavinato RA, Cassis P, et al. Complement Alternative Pathway Deficiency in Recipients Protects Kidney complement system is involved throughout the whole process of kidney transplantation. Uncontrolled complement cleavage cascade in deceased donors and IRI predispose the allograft to DGF. During this process, the complement system serves predominantly as part of the innate immune response through assembling MAC and orchestrating the inflammatory response. Growing evidence indicates that the complement components could also bridge the innate and adaptive immune responses and are involved in the development of TCMR and AMR after kidney transplantation. The emerging intracellular complement system plays the central role in this scenario, especially in the regulation of T-cell activity and homeostasis. The involvement of the complement system in kidney transplantation makes it an ideal predictive tool and a promising therapeutic target in the clinical setting. Results from animal models and clinical trials suggested that interfering complement activation before organ procurement, during kidney preservation, and in kidney transplant recipients were all plausible strategies to improve allograft outcomes. Future investigations in this field need to focus on the intracellular complement components and those locally produced in the kidney and to further improve the targeting efficiency of these therapies.

\section{AUTHOR CONTRIBUTIONS}

WQ conceived this review. RQ collected and analyzed literatures and drafted the manuscript. WQ helped revise the language. All authors read and approved the final manuscript.

\section{ACKNOWLEDGMENTS}

This work was supported by the National Natural Science Foundation of China (81772734 to WQ).

Allograft From Ischemia/Reperfusion Injury and Alloreactive T Cell Response. Am J Transplant (2017) 17(9):2312-25. doi: 10.1111/ajt.14262

8. Asgari E, Farrar CA, Lynch N, Ali YM, Roscher S, Stover C, et al. MannanBinding Lectin-Associated Serine Protease 2 Is Critical for the Development of Renal Ischemia Reperfusion Injury and Mediates Tissue Injury in the Absence of Complement C4. FASEB J Off Publ Fed Am Soc Exp Biol (2014) 28(9):39964003. doi: 10.1096/fj.13-246306

9. Howard MC, Nauser CL, Farrar CA, Wallis R, Sacks SH. L-Fucose Prevention of Renal Ischaemia/Reperfusion Injury in Mice. FASEB J Off Publ Fed Am Soc Exp Biol (2020) 34(1):822-34. doi: 10.1096/fj.201901582R

10. Cravedi P, Heeger PS. Complement as a Multifaceted Modulator of Kidney Transplant Injury. J Clin Invest (2014) 124(6):2348-54. doi: 10.1172/JCI72273

11. Brar JE, Quigg RJ. Complement Activation in the Tubulointerstitium: AKI, CKD, and in Between. Kidney Int (2014) 86(4):663-6. doi: 10.1038/ ki.2014.168

12. Xavier S, Sahu RK, Bontha SV, Mass V, Taylor RP, Megyesi J, et al. Complement C1r Serine Protease Contributes to Kidney Fibrosis. Am J Physiol Renal Physiol (2019) 317(5):F1293-f1304. doi: 10.1152/ajprenal.00357.2019

13. Peng Q, Wu W, Wu KY, Cao B, Qiang C, Li K, et al. The C5a/C5aR1 Axis Promotes Progression of Renal Tubulointerstitial Fibrosis in a Mouse Model of Renal Ischemia/Reperfusion Injury. Kidney Int (2019) 96(1):117-28. doi: 10.1016/j.kint.2019.01.039 
14. Tang Z, Lu B, Hatch E, Sacks SH, Sheerin NS. C3a Mediates Epithelial-ToMesenchymal Transition in Proteinuric Nephr Opathy. JASN (2009) 20 (3):593-603. doi: 10.1681/ASN.2008040434

15. Cui J, Wu X, Song Y, Chen Y, Wan J. Complement C3 Exacerbates Renal Interstitial Fibrosis by Facilitating the M1 Macrophage Phenotype in a Mouse Model of Unilateral Ureteral Obstruction. Am J Physiol Renal Physiol (2019) 317(5):F1171-f1182. doi: 10.1152/ajprenal.00165.2019

16. West EE, Kunz N, Kemper C. Complement and Human T Cell Metabolism: Location, Location, Location. Immunol Rev (2020) 295(1):68-81. doi: 10.1111/ imr. 12852

17. West EE, Kolev M, Kemper C. Complement and the Regulation of T Cell Responses. Annu Rev Immunol (2018) 36:309-38. doi: 10.1146/annurevimmunol-042617-053245

18. Miao J, Lesher AM, Miwa T, Sato S, Gullipalli D, Song WC. Tissue-Specific Deletion of Crry From Mouse Proximal Tubular Epithelial Cells Increases Susceptibility to Renal Ischemia-Reperfusion Injury. Kidney Int (2014) 86 (4):726-37. doi: 10.1038/ki.2014.103

19. Yamada K, Miwa T, Liu J, Nangaku M, Song WC. Critical Protection From Renal Ischemia Reperfusion Injury by CD55 and CD59. J Immunol (2004) 172 (6):3869-75. doi: 10.4049/jimmunol.172.6.3869

20. Brodsky RA. Paroxysmal Nocturnal Hemoglobinuria. Blood (2014) 124 (18):2804-11. doi: 10.1182/blood-2014-02-522128

21. Roozendaal R, Carroll MC. Complement Receptors CD21 and CD35 in Humoral Immunity. Immunol Rev (2007) 219:157-66. doi: 10.1111/j.1600065X.2007.00556.x

22. Renner B, Ferreira VP, Cortes C, Goldberg R, Ljubanovic D, Pangburn MK, et al. Binding of Factor $\mathrm{H}$ to Tubular Epithelial Cells Limits Interstitial Complement Activation in Ischemic Injury. Kidney Int (2011) 80(2):16573. doi: $10.1038 / \mathrm{ki} .2011 .115$

23. Berger M, Lefaucheur C, Jordan SC. Update on C1 Esterase Inhibitor in Human Solid Organ Transplantation. Transplantation (2019) 103(9):176375. doi: 10.1097/TP.0000000000002717

24. Wu Y, Zwaini ZD, Brunskill NJ, Zhang X, Wang H, Chana R, et al. Properdin Deficiency Impairs Phagocytosis and Enhances Injury at Kidney Repair Phase Post Ischemia-Reperfusion. Front Immunol (2021) 12:697760. doi: 10.3389/ fimmu.2021.697760

25. Khera R, Das N. Complement Receptor 1: Disease Associations and Therapeutic Implications. Mol Immunol (2009) 46(5):761-72. doi: 10.1016/ j.molimm.2008.09.026

26. Oliveira LC, Kretzschmar GC, dos Santos ACM, Camargo CM, Nisihara RM, Farias TDJ, et al. Complement Receptor 1 (CR1, CD35) Polymorphisms and Soluble CR1: A Proposed Anti-Inflammatory Role to Quench the Fire of "Fogo Selvagem" Pemphigus Foliaceus. Front Immunol (2019) 10(2585). doi: 10.3389/fimmu.2019.02585

27. Vorup-Jensen T, Jensen RK. Structural Immunology of Complement Receptors 3 and 4. Front Immunol (2018) 9(2716). doi: 10.3389/fimmu. 2018.02716

28. Jensen RK, Bajic G, Sen M, Springer TA, Vorup-Jensen T, Andersen GR. Complement Receptor 3 Forms a Compact High-Affinity Complex With Ic3b. J Immunol (2021) 206(12):3032-42. doi: 10.4049/jimmunol.2001208

29. Wagner C, Hänsch GM, Stegmaier S, Denefleh B, Hug F, Schoels M. The Complement Receptor 3, CR3 (CD11b/CD18), on T Lymphocytes: Activation-Dependent Up-Regulation and Regulatory Function. Eur J Immunol (2001) 31(4):1173-80. doi: 10.1002/1521-4141(200104)31:4<1173:: AID-IMMU1173>3.0.CO;2-9

30. Choudhry N, Li K, Zhang T, Wu KY, Song Y, Farrar CA, et al. The Complement Factor 5a Receptor 1 has a Pathogenic Role in Chronic Inflammation and Renal Fibrosis in a Murine Model of Chronic Pyelonephritis. Kidney Int (2016) 90 (3):540-54. doi: 10.1016/j.kint.2016.04.023

31. Zhang T, Wu KY, Ma N, Wei LL, Garstka M, Zhou W, et al. The C5a/C5aR2 Axis Promotes Renal Inflammation and Tissue Damage. JCI Insight (2020) 5 (7). doi: 10.1172/jci.insight.134081

32. Poppelaars F, van Werkhoven MB, Kotimaa J, Veldhuis ZJ, Ausema A, Broeren SGM, et al. Critical Role for Complement Receptor C5aR2 in the Pathogenesis of Renal Ischemia-Reperfusion Injury. FASEB J Off Publ Fed Am Soc Exp Biol (2017) 31(7):3193-204. doi: 10.1096/fj.201601218R

33. Helmy KY, Katschke KJJr., Gorgani NN, Kljavin NM, Elliott JM, Diehl L, et al. CRIg: A Macrophage Complement Receptor Required for Phagocytosis of
Circulating Pathogens. Cell (2006) 124(5):915-27. doi: 10.1016/ j.cell.2005.12.039

34. Gorgani NN, He JQ, Katschke KJ Jr., Helmy KY, Xi H, Steffek M, et al. Complement Receptor of the Ig Superfamily Enhances ComplementMediated Phagocytosis in a Subpopulation of Tissue Resident Macrophages. J Immunol (2008) 181(11):7902-8. doi: 10.4049/jimmunol.181.11.7902

35. Tanaka M, Nagai T, Usami M, Hasui K, Takao S, Matsuyama T. Phenotypic and Functional Profiles of CRIg (Z39Ig)-Expressing Macrophages in the Large Intestine. Innate Immun (2012) 18(2):258-67. doi: 10.1177/ 1753425911400641

36. Holers VM, Kulik L. Complement Receptor 2, Natural Antibodies and Innate Immunity: Inter-Relationships in B Cell Selection and Activation. Mol Immunol (2007) 44(1-3):64-72. doi: 10.1016/j.molimm.2006.07.003

37. Halkjær L, Troldborg A, Pedersen H, Jensen L, Hansen AG, Hansen TK, et al. Complement Receptor 2 Based Immunoassay Measuring Activation of the Complement System at C3-Level in Plasma Samples From Mice and Humans. Front Immunol (2020) 11:774. doi: 10.3389/fimmu.2020.00774

38. Smith NA, Coleman CB, Gewurz BE, Rochford R. CD21 (Complement Receptor 2) Is the Receptor for Epstein-Barr Virus Entry Into $\mathrm{T}$ Cells. J Virol (2020) 94(11). doi: 10.1128/JVI.00428-20

39. Halder LD, Jo EAH, Hasan MZ, Ferreira-Gomes M, Kruger T, Westermann $\mathrm{M}$, et al. Immune Modulation by Complement Receptor 3-Dependent Human Monocyte TGF- $\beta 1$-Transporting Vesicles. Nat Commun (2020) 11(1):2331. doi: 10.1038/s41467-020-16241-5

40. Barbour TD, Ling GS, Ruseva MM, Fossati-Jimack L, Cook HT, Botto M, et al. Complement Receptor 3 Mediates Renal Protection in Experimental C3 Glomerulopathy. Kidney Int (2016) 89(4):823-32. doi: 10.1016/ j.kint.2015.11.024

41. Fayyazi A, Scheel O, Werfel T, Schweyer S, Oppermann M, Gotze O, et al. The C5a Receptor is Expressed in Normal Renal Proximal Tubular But Not in Normal Pulmonary or Hepatic Epithelial Cells. Immunology (2000) 99(1):3845. doi: 10.1046/j.1365-2567.2000.00911.x

42. Peng Q, Li K, Smyth LA, Xing G, Wang N, Meader L, et al. C3a and C5a Promote Renal Ischemia-Reperfusion Injury. J Am Soc Nephrol JASN (2012) 23(9):1474-85. doi: 10.1681/ASN.2011111072

43. Arias-Cabrales C, Rodriguez-Garcia E, Gimeno J, Benito D, Perez-Saez MJ, Redondo-Pachon D, et al. Role of C5aR1 and C5L2 Receptors in IschemiaReperfusion Injury. J Clin Med (2021) 10(5). doi: 10.3390/jcm10050974

44. Li R, Coulthard LG, Wu MC, Taylor SM, Woodruff TM. C5L2: A Controversial Receptor of Complement Anaphylatoxin, C5a. FASEB J Off Publ Fed Am Soc Exp Biol (2013) 27(3):855-64. doi: 10.1096/fj.12-220509

45. Thorenz A, Derlin K, Schröder C, Dressler L, Vijayan V, Pradhan P, et al. Enhanced Activation of Interleukin-10, Heme Oxygenase-1, and AKT in C5aR2-Deficient Mice is Associated With Protection From Ischemia Reperfusion Injury-Induced Inflammation and Fibrosis. Kidney Int (2018) 94(4):741-55. doi: 10.1016/j.kint.2018.04.005

46. Hu C, Li L, Ding P, Li L, Ge X, Zheng L, et al. Complement Inhibitor CRIg/FH Ameliorates Renal Ischemia Reperfusion Injury via Activation of PI3K/AKT Signaling. J Immunol (2018) 201(12):3717-30. doi: 10.4049/jimmunol.1800987

47. Sacks SH, Zhou W. Locally Produced Complement and its Role in Renal Allograft Rejection. Am J Transplant (2003) 3(8):927-32. doi: 10.1034/j.16006143.2003.00175.x

48. Farrar CA, Asgari E, Schwaeble WJ, Sacks SH. Which Pathways Trigger the Role of Complement in Ischaemia/Reperfusion Injury? Front Immunol (2012) 3:341. doi: 10.3389/fimmu.2012.00341

49. Farrar CA, Zhou W, Lin T, Sacks SH. Local Extravascular Pool of C3 is a Determinant of Postischemic Acute Renal Failure. FASEB J Off Publ Fed Am Soc Exp Biol (2006) 20(2):217-26. doi: 10.1096/fj.05-4747com

50. Zheng X, Feng B, Chen G, Zhang X, Li M, Sun H, et al. Preventing Renal Ischemia-Reperfusion Injury Using Small Interfering RNA by Targeting Complement 3 Gene. Am J Transplant (2006) 6(9):2099-108. doi: 10.1111/ j.1600-6143.2006.01427.x

51. Zheng X, Zhang X, Sun H, Feng B, Li M, Chen G, et al. Protection of Renal Ischemia Injury Using Combination Gene Silencing of Complement 3 and Caspase 3 Genes. Transplantation (2006) 82(12):1781-6. doi: 10.1097/ 01.tp.0000250769.86623.a3

52. Thurman JM, Ljubanovic D, Edelstein CL, Gilkeson GS, Holers VM. Lack of a Functional Alternative Complement Pathway Ameliorates Ischemic Acute 
Renal Failure in Mice. J Immunol (2003) 170(3):1517-23. doi: 10.4049/ jimmunol.170.3.1517

53. Thurman JM, Ljubanović D, Royer PA, Kraus DM, Molina H, Barry NP, et al. Altered Renal Tubular Expression of the Complement Inhibitor Crry Permits Complement Activation After Ischemia/Reperfusion. J Clin Invest (2006) 116 (2):357-68. doi: 10.1172/JCI24521

54. Thurman JM, Royer PA, Ljubanovic D, Dursun B, Lenderink AM, Edelstein CL, et al. Treatment With an Inhibitory Monoclonal Antibody to Mouse Factor B Protects Mice From Induction of Apoptosis and Renal Ischemia/ Reperfusion Injury. J Am Soc Nephrol JASN (2006) 17(3):707-15. doi: 10.1681/ ASN.2005070698

55. Goetz L, Laskowski J, Renner B, Pickering MC, Kulik L, Klawitter J, et al. Complement Factor H Protects Mice From Ischemic Acute Kidney Injury But is Not Critical for Controlling Complement Activation by Glomerular IgM. Eur J Immunol (2018) 48(5):791-802. doi: 10.1002/eji.201747240

56. Castellano G, Melchiorre R, Loverre A, Ditonno P, Montinaro V, Rossini M, et al. Therapeutic Targeting of Classical and Lectin Pathways of Complement Protects From Ischemia-Reperfusion-Induced Renal Damage. Am J Pathol (2010) 176(4):1648-59. doi: 10.2353/ajpath.2010.090276

57. van der Pol P, Schlagwein N, van Gijlswijk DJ, Berger SP, Roos A, Bajema IM, et al. Mannan-Binding Lectin Mediates Renal Ischemia/Reperfusion Injury Independent of Complement Activation. Am J Transplant (2012) 12(4):87787. doi: 10.1111/j.1600-6143.2011.03887.x

58. Howard MC, Nauser CL, Vizitiu DA, Sacks SH. Fucose as a New Therapeutic Target in Renal Transplantation. Pediatr Nephrol (Berlin Germany) (2021) 36 (5):1065-73. doi: 10.1007/s00467-020-04588-2

59. Bongoni AK, Lu B, Salvaris EJ, Roberts V, Fang D, McRae JL, et al. Overexpression of Human CD55 and CD59 or Treatment With Human CD55 Protects Against Renal Ischemia-Reperfusion Injury in Mice. J Immunol (2017) 198(12):4837-45. doi: 10.4049/jimmunol.1601943

60. Gueler F, Rong S, Gwinner W, Mengel M, Brocker V, Schon S, et al. Complement 5a Receptor Inhibition Improves Renal Allograft Survival. J Am Soc Nephrol JASN (2008) 19(12):2302-12. doi: 10.1681/ASN.2007111267

61. Thurman JM, Lenderink AM, Royer PA, Coleman KE, Zhou J, Lambris JD, et al. C3a Is Required for the Production of CXC Chemokines by Tubular Epithelial Cells After Renal Ishemia/Reperfusion. J Immunol (2007) 178 (3):1819-28. doi: 10.4049/jimmunol.178.3.1819

62. Arumugam TV, Shiels IA, Strachan AJ, Abbenante G, Fairlie DP, Taylor SM. A Small Molecule C5a Receptor Antagonist Protects Kidneys From Ischemia/ Reperfusion Injury in Rats. Kidney Int (2003) 63(1):134-42. doi: 10.1046/ j.1523-1755.2003.00737.x

63. de Vries B, Köhl J, Leclercq WK, Wolfs TG, van Bijnen AA, Heeringa P, et al. Complement Factor C5a Mediates Renal Ischemia-Reperfusion Injury Independent From Neutrophils. J Immunol (2003) 170(7):3883-9. doi: 10.4049/jimmunol.170.7.3883

64. Zheng X, Zhang X, Feng B, Sun H, Suzuki M, Ichim T, et al. Gene Silencing of Complement C5a Receptor Using siRNA for Preventing Ischemia/ Reperfusion Injury. Am J Pathol (2008) 173(4):973-80. doi: 10.2353/ ajpath.2008.080103

65. Castellano G, Franzin R, Sallustio F, Stasi A, Banelli B, Romani M, et al. Complement Component C5a Induces Aberrant Epigenetic Modifications in Renal Tubular Epithelial Cells Accelerating Senescence by Wnt4/betacatenin Signaling After Ischemia/Reperfusion Injury. Aging (Albany NY) (2019) 11 (13):4382-406. doi: 10.18632/aging.102059

66. Wu MCL, Lee JD, Ruitenberg MJ, Woodruff TM. Absence of the C5a Receptor C5aR2 Worsens Ischemic Tissue Injury by Increasing C5aR1-Mediated Neutrophil Infiltration. J Immunol (2020) 205(10):2834-9. doi: 10.4049/jimmunol.2000778

67. Luo S, Hu D, Wang M, Zipfel PF, Hu Y. Complement in Hemolysis- and Thrombosis- Related Diseases. Front Immunol (2020) 11:1212. doi: 10.3389/ fimmu.2020.01212

68. Kozarcanin H, Lood C, Munthe-Fog L, Sandholm K, Hamad OA, Bengtsson $\mathrm{AA}$, et al. The Lectin Complement Pathway Serine Proteases (MASPs) Represent a Possible Crossroad Between the Coagulation and Complement Systems in Thromboinflammation. J Thromb Haemost JTH (2016) 14(3):53145. doi: $10.1111 /$ jth. 13208

69. Amara U, Flierl MA, Rittirsch D, Klos A, Chen H, Acker B, et al. Molecular Intercommunication Between the Complement and Coagulation Systems. J Immunol (2010) 185(9):5628-36. doi: 10.4049/jimmunol.0903678
70. Foley JH, Walton BL, Aleman MM, O'Byrne AM, Lei V, Harrasser M, et al. Complement Activation in Arterial and Venous Thrombosis is Mediated by Plasmin. EBioMedicine (2016) 5:175-82. doi: 10.1016/j.ebiom.2016.02.011

71. Krisinger MJ, Goebeler V, Lu Z, Meixner SC, Myles T, Pryzdial EL, et al. Thrombin Generates Previously Unidentified C5 Products That Support the Terminal Complement Activation Pathway. Blood (2012) 120(8):1717-25. doi: 10.1182/blood-2012-02-412080

72. Stallone G, Pontrelli P, Rascio F, Castellano G, Gesualdo L, Grandaliano G. Coagulation and Fibrinolysis in Kidney Graft Rejection. Front Immunol (2020) 11:1807. doi: 10.3389/fimmu.2020.01807

73. Pontrelli P, Cariello M, Rascio F, Gigante M, Verrienti R, Tataranni T, et al. Thrombin may Modulate Dendritic Cell Activation in Kidney Transplant Recipients With Delayed Graft Function. Nephrol Dial Transplant Off Publ Eur Dialysis Transplant Assoc - Eur Renal Assoc (2015) 30(9):1480-7. doi: 10.1093/ndt/gfv129

74. Thomas AM, Gerogianni A, McAdam MB, Floisand Y, Lau C, Espevik T, et al. Complement Component C5 and TLR Molecule CD14 Mediate HemeInduced Thromboinflammation in Human Blood. J Immunol (2019) 203 (6):1571-8. doi: 10.4049/jimmunol.1900047

75. Wang L, Vijayan V, Jang MS, Thorenz A, Greite R, Rong S, et al. Labile Heme Aggravates Renal Inflammation and Complement Activation After Ischemia Reperfusion Injury. Front Immunol (2019) 10:2975. doi: 10.3389/ fimmu.2019.02975

76. Jackson SP, Darbousset R, Schoenwaelder SM. Thromboinflammation: Challenges of Therapeutically Targeting Coagulation and Other Host Defense Mechanisms. Blood (2019) 133(9):906-18. doi: 10.1182/blood2018-11-882993

77. Simone S, Rascio F, Castellano G, Divella C, Chieti A, Ditonno P, et al. Complement-Dependent NADPH Oxidase Enzyme Activation in Renal Ischemia/Reperfusion Injury. Free Radical Biol Med (2014) 74:263-73. doi: 10.1016/j.freeradbiomed.2014.07.003

78. Qi R, Yang C. Renal Tubular Epithelial Cells: The Neglected Mediator of Tubulointerstitial Fibrosis After Injury. Cell Death Dis (2018) 9(11):1126. doi: 10.1038/s41419-018-1157-x

79. Delpech PO, Thuillier R, SaintYves T, Danion J, Le Pape S, van Amersfoort ES, et al. Inhibition of Complement Improves Graft Outcome in a Pig Model of Kidney Autotransplantation. J Trans Med (2016) 14(1):277. doi: 10.1186/ s12967-016-1013-7

80. Danobeitia JS, Ziemelis M, Ma X, Zitur LJ, Zens T, Chlebeck PJ, et al. Complement Inhibition Attenuates Acute Kidney Injury After IschemiaReperfusion and Limits Progression to Renal Fibrosis in Mice. PloS One (2017) 12(8):e0183701. doi: 10.1371/journal.pone.0183701

81. Durigutto P, Sblattero D, Biffi S, De Maso L, Garrovo C, Baj G, et al. Targeted Delivery of Neutralizing Anti-C5 Antibody to Renal Endothelium Prevents Complement-Dependent Tissue Damage. Front Immunol (2017) 8:1093. doi: 10.3389/fimmu.2017.01093

82. Błogowski W, Dołęgowska B, Sałata D, Budkowska M, Domański L, Starzyńska T. Clinical Analysis of Perioperative Complement Activity During Ischemia/Reperfusion Injury Following Renal Transplantation. Clin J Am Soc Nephrol (2012) 7(11):1843-51. doi: 10.2215/CJN.02200312

83. Damman J, Schuurs TA, Ploeg RJ, Seelen MA. Complement and Renal Transplantation: From Donor to Recipient. Transplantation (2008) 85 (7):923-7. doi: 10.1097/TP.0b013e3181683cf5

84. Damman J, Bloks VW, Daha MR, van der Most PJ, Sanjabi B, van der Vlies P, et al. Hypoxia and Complement-And-Coagulation Pathways in the Deceased Organ Donor as the Major Target for Intervention to Improve Renal Allograft Outcome. Transplantation (2015) 99(6):1293-300. doi: 10.1097/TP. 0000000000000500

85. de Vries DK, van der Pol P, van Anken GE, van Gijlswijk DJ, Damman J, Lindeman JH, et al. Acute But Transient Release of Terminal Complement Complex After Reperfusion in Clinical Kidney Transplantation. Transplantation (2013) 95(6):816-20. doi: 10.1097/TP.0b013e31827e31c9

86. Bartoszek D, Mazanowska O, Kościelska-Kasprzak K, Kaminska D, Lepiesza A, Chudoba P, et al. Functional Activity of the Complement System in Deceased Donors in Relation to Kidney Allograft Outcome. Transplant Proc (2018) 50(6):1697-700. doi: 10.1016/j.transproceed.2018.02.157

87. Arias-Cabrales CE, Riera M, Pérez-Sáez MJ, Gimeno J, Benito D, Redondo D, et al. Activation of Final Complement Components After Kidney 
Transplantation as a Marker of Delayed Graft Function Severity. Clin Kidney J (2021) 14(4):1190-6. doi: 10.1093/ckj/sfaa147

88. Damman J, Kok JL, Snieder H, Leuvenink HG, van Goor H, Hillebrands JL, et al. Lectin Complement Pathway Gene Profile of the Donor and Recipient Does Not Influence Graft Outcome After Kidney Transplantation. Mol Immunol (2012) 50(1-2):1-8. doi: 10.1016/j.molimm.2011.11.009

89. Ermini L, Weale ME, Brown KM, Mesa IR, Howell WM, Vaughan R, et al. Systematic Assessment of the Influence of Complement Gene Polymorphisms on Kidney Transplant Outcome. Immunobiology (2016) 221(4):528-34. doi: 10.1016/j.imbio.2015.12.006

90. Michielsen LA, van Zuilen AD, Muskens IS, Verhaar MC, Otten HG. Complement Polymorphisms in Kidney Transplantation: Critical in Graft Rejection? Am J Transplant (2017) 17(8):2000-7. doi: 10.1111/ajt.14199

91. Vonbrunn E, Ries T, Söllner S, Muller-Deile J, Buttner-Herold M, Amann K, et al. Multiplex Gene Analysis Reveals T-Cell and Antibody-Mediated Rejection-Specific Upregulation of Complement in Renal Transplants. Sci Rep (2021) 11(1):15464. doi: 10.1038/s41598-021-94954-3

92. Yu ZX, Qi S, Lasaro MA, Bouchard K, Dow C, Moore K, et al. Targeting Complement Pathways During Cold Ischemia and Reperfusion Prevents Delayed Graft Function. Am J Transplant (2016) 16(9):2589-97. doi: 10.1111/ajt.13797

93. Kassimatis T, Qasem A, Douiri A, Ryan EG, Rebollo-Mesa I, Nichols LL, et al. A Double-Blind Randomised Controlled Investigation Into the Efficacy of Mirococept (APT070) for Preventing Ischaemia Reperfusion Injury in the Kidney Allograft (EMPIRIKAL): Study Protocol for a Randomised Controlled Trial. Trials (2017) 18(1):255. doi: 10.1186/s13063-017-1972-x

94. Kassimatis T, Greenlaw R, Hunter JP, Douiri A, Flach C, Rebollo-Mesa I, et al. Ex Vivo Delivery of Mirococept: A Dose-Finding Study in Pig Kidney After Showing a Low Dose is Insufficient to Reduce Delayed Graft Function in Human Kidney. Am J Transplant (2021) 21(3):1012-26. doi: 10.1111/ ajt.16265

95. Zheng X, Zang G, Jiang J, He W, Johnston NJ, Ling H, et al. Attenuating Ischemia-Reperfusion Injury in Kidney Transplantation by Perfusing Donor Organs With siRNA Cocktail Solution. Transplantation (2016) 100(4):74352. doi: 10.1097/TP.0000000000000960

96. Stax AM, Gelderman KA, Schlagwein N, Essers MC, Kamerling SW, Woltman $\mathrm{AM}$, et al. Induction of Donor-Specific T-Cell Hyporesponsiveness Using Dexamethasone-Treated Dendritic Cells in Two Fully Mismatched Rat Kidney Transplantation Models. Transplantation (2008) 86(9):1275-82. doi: 10.1097/TP.0b013e31818a6682

97. van Kooten C, Fiore N, Trouw LA, Csomor E, Xu W, Castellano G, et al. Complement Production and Regulation by Dendritic Cells: Molecular Switches Between Tolerance and Immunity. Mol Immunol (2008) 45 (16):4064-72. doi: 10.1016/j.molimm.2008.07.015

98. Li K, Fazekasova H, Wang N, Sagoo P, Peng Q, Khamri W, et al. Expression of Complement Components, Receptors and Regulators by Human Dendritic Cells. Mol Immunol (2011) 48(9-10):1121-7. doi: 10.1016/j.molimm.2011.02.003

99. Peng Q, Li K, Patel H, Sacks SH, Zhou W. Dendritic Cell Synthesis of C3 Is Required for Full T Cell Activation and Development of a Th1 Phenotype. J Immunol (2006) 176(6):3330-41. doi: 10.4049/jimmunol.176.6.3330

100. Zhou W, Peng Q, Li K, Sacks SH. Role of Dendritic Cell Synthesis of Complement in the Allospecific T Cell Response. Mol Immunol (2007) 44(13):57-63. doi: 10.1016/j.molimm.2006.06.012

101. Peng Q, Li K, Anderson K, Farrar CA, Lu B, Smith RA, et al. Local Production and Activation of Complement Up-Regulates the Allostimulatory Function of Dendritic Cells Through C3a-C3aR Interaction. Blood (2008) 111(4):2452-61. doi: 10.1182/blood-2007-06095018

102. Cravedi P, Leventhal J, Lakhani P, Ward SC, Donovan MJ, Heeger PS. Immune Cell-Derived C3a and C5a Costimulate Human T Cell Alloimmunity. Am J Transplant (2013) 13(10):2530-9. doi: 10.1111/ ajt. 12405

103. Sheen JH, Strainic MG, Liu J, Zhang W, Yi Z, Medof ME, et al. TLR-Induced Murine Dendritic Cell (DC) Activation Requires DC-Intrinsic Complement. J Immunol (2017) 199(1):278-91. doi: 10.4049/jimmunol.1700339

104. West EE, Afzali B, Kemper C. Unexpected Roles for Intracellular Complement in the Regulation of Th1 Responses. Adv Immunol (2018) 138:35-70. doi: 10.1016/bs.ai.2018.02.001
105. Hosszu KK, Santiago-Schwarz F, Peerschke EI, Ghebrehiwet B. Evidence That a $\mathrm{C} 1 \mathrm{q} / \mathrm{C} 1 \mathrm{qR}$ System Regulates Monocyte-Derived Dendritic Cell Differentiation at the Interface of Innate and Acquired Immunity. Innate Immun (2010) 16(2):115-27. doi: 10.1177/1753425909339815

106. Teh BK, Yeo JG, Chern LM, Lu J. C1q Regulation of Dendritic Cell Development From Monocytes With Distinct Cytokine Production and T Cell Stimulation. Mol Immunol (2011) 48(9-10):1128-38. doi: 10.1016/ j.molimm.2011.02.006

107. Mascarell L, Airouche S, Berjont N, Gary C, Gueguen C, Fourcade G, et al. The Regulatory Dendritic Cell Marker C1q is a Potent Inhibitor of Allergic Inflammation. Mucosal Immunol (2017) 10(3):695-704. doi: 10.1038/ mi.2016.87

108. Munawara U, Perveen K, Small AG, Putty T, Quach A, Gorgani NN, et al. Human Dendritic Cells Express the Complement Receptor Immunoglobulin Which Regulates T Cell Responses. Front Immunol (2019) 10:2892. doi: 10.3389/fimmu.2019.02892

109. Lalli PN, Strainic MG, Yang M, Lin F, Medof ME, Heeger PS. Locally Produced C5a Binds to T Cell-Expressed C5aR to Enhance Effector T-Cell Expansion by Limiting Antigen-Induced Apoptosis. Blood (2008) 112 (5):1759-66. doi: 10.1182/blood-2008-04-151068

110. Liszewski MK, Kolev M, Le Friec G, Leung M, Bertram PG, Fara AF, et al. Intracellular Complement Activation Sustains $\mathrm{T}$ Cell Homeostasis and Mediates Effector Differentiation. Immunity (2013) 39(6):1143-57. doi: 10.1016/j.immuni.2013.10.018

111. Hess C, Kemper C. Complement-Mediated Regulation of Metabolism and Basic Cellular Proces Ses. Immunity (2016) 45(2):240-54. doi: 10.1016/ j.immuni.2016.08.003

112. Kolev M, Dimeloe S, Le Friec G, Navarini A, Arbore G, Povoleri GA, et al. Complement Regulates Nutrient Influx and Metabolic Reprogramming During Th1 Cell Responses. Immunity (2015) 42(6):1033-47. doi: 10.1016/ j.immuni.2015.05.024

113. Arbore G, West EE, Rahman J, Le Friec G, Niyonzima N, Pirooznia M, et al. Complement Receptor CD46 Co-Stimulates Optimal Human CD8(+) T Cell Effector Function via Fatty Acid Metabolism. Nat Commun (2018) 9 (1):4186. doi: 10.1038/s41467-018-06706-Z

114. Trailin A, Mrazova P, Hruba P, Voska L, Sticova E, Slavcev A, et al. Chronic Active Antibody-Mediated Rejection Is Associated With the Upregulation of Interstitial But Not Glomerular Transcripts. Front Immunol (2021) 12:729558. doi: 10.3389/fimmu.2021.729558

115. Arbore G, West EE, Spolski R, Robertson AAB, Klos A, Rheinheimer C, et al. T Helper 1 Immunity Requires Complement-Driven NLRP3 Inflammasome Activity in CD4(+) T Cells. Science (2016) 352(6292):aad1210. doi: 10.1126/ science.aad 1210

116. Arbore G, Kemper C, Kolev M. Intracellular Complement - the Complosome - in Immune Cell Regulation. Mol Immunol (2017) 89:2-9. doi: 10.1016/ j.molimm.2017.05.012

117. Ni Choileain S, Weyand NJ, Neumann C, Thomas J, So M, Astier AL. The Dynamic Processing of CD46 Intracellular Domains Provides a Molecular Rheostat for T Cell Activation. PloS One (2011) 6(1):e16287. doi: 10.1371/ journal.pone.0016287

118. Michielsen LA, van Zuilen AD, Kardol-Hoefnagel T, Verhaar MC, Otten HG. Association Between Promoter Polymorphisms in CD46 and CD59 in Kidney Donors and Transplant Outcome. Front Immunol (2018) 9:972. doi: 10.3389/fimmu.2018.00972

119. Samy KP, Gao Q, Davis RP, Song M, Fitch ZW, Mulvihill MS, et al. The Role of Human CD46 in Early Xenoislet Engraftment in a Dual Transplant Model. Xenotransplantation (2019) 26(6):e12540. doi: 10.1111/xen.12540

120. Song M, Fitch ZW, Samy KP, Martin BM, Gao Q, Patrick Davis R, et al. Coagulation, Inflammation, and CD46 Transgene Expression in Neonatal Porcine Islet Xenotransplantation. Xenotransplantation (2021) 28(3):e12680. doi: $10.1111 /$ xen. 12680

121. Patel R, Mickey MR, Terasaki PI. Serotyping for Homotransplantation. XVI. Analysis of Kidney Transplants From Unrelated Donors. New Engl J Med (1968) 279(10):501-6. doi: 10.1056/NEJM196809052791001

122. Feucht HE, Felber E, Gokel MJ, Hillebrand G, Nattermann U, Brockmeyer C, et al. Vascular Deposition of Complement-Split Products in Kidney Allografts With Cell-Mediated Rejection. Clin Exp Immunol (1991) 86 (3):464-70. doi: 10.1111/j.1365-2249.1991.tb02954.x 
123. Gonzalez SF, Lukacs-Kornek V, Kuligowski MP, Pitcher LA, Degn SE, Turley SJ, et al. Complement-Dependent Transport of Antigen Into B Cell Follicles. J Immunol (2010) 185(5):2659-64. doi: 10.4049/jimmunol.1000522

124. Stites E, Le Quintrec M, Thurman JM. The Complement System and Antibody-Mediated Transplant Rejection. J Immunol (2015) 195(12):552531. doi: 10.4049/jimmunol.1501686

125. Frémeaux-Bacchi V, Legendre CM. The Emerging Role of Complement Inhibitors in Transplantation. Kidney Int (2015) 88(5):967-73. doi: 10.1038/ki.2015.253

126. Haas M, Sis B, Racusen LC, Solez K, Glotz D, Colvin RB, et al. Banff 2013 Meeting Report: Inclusion of C4d-Negative Antibody-Mediated Rejection and Antibody-Associated Arterial Lesions. Am J Transplant (2014) 14 (2):272-83. doi: 10.1111/ajt.12590

127. Orandi BJ, Alachkar N, Kraus ES, Naqvi F, Lonze BE, Lees L, et al. Presentation and Outcomes of C4d-Negative Antibody-Mediated Rejection After Kidney Transplantation. Am J Transplant (2016) 16(1):213-20. doi: 10.1111/ajt.13434

128. Roufosse C, Simmonds N, Clahsen-van Groningen M, Haas M, Henriksen KJ, Horsfield C, et al. A 2018 Reference Guide to the Banff Classification of Renal Allograft Pathology. Transplantation (2018) 102(11):1795-814. doi: 10.1097/TP.0000000000002366

129. Allison SJ. Transplantation: Prognostic Value of C3d-Binding DSA. Nat Rev Nephrol (2014) 10(10):543. doi: 10.1038/nrneph.2014.165

130. Sicard A, Ducreux S, Rabeyrin M, Couzi L, McGregor B, Badet L, et al. Detection of C3D-Binding Donor-Specific Anti-HLA Antibodies at Diagnosis of Humoral Rejection Predicts Renal Graft Loss. J Am Soc Nephrol JASN (2015) 26(2):457-67. doi: 10.1681/ASN.2013101144

131. Comoli P, Cioni M, Tagliamacco A, Quartuccio G, Innocente A, Fontana I, et al. Acquisition of C3d-Binding Activity by De Novo Donor-Specific HLA Antibodies Correlates With Graft Loss in Nonsensitized Pediatric Kidney Recipients. Am J Transplant (2016) 16(7):2106-16. doi: 10.1111/ajt.13700

132. Lee H, Han E, Choi AR, Ban TH, Chung BH, Yang CW, et al. Clinical Impact of Complement (C1q, C3d) Binding De Novo Donor-Specific HLA Antibody in Kidney Transplant Recipients. PloS One (2018) 13(11):e0207434. doi: 10.1371/journal.pone.0207434

133. Pelletier RP, Balazs I, Adams P, Rajab A, DiPaola NR, Henry ML. Clinical Utility of C3d Binding Donor-Specific Anti-Human Leukocyte Antigen Antibody Detection by Single Antigen Beads After Kidney Transplantation-a Retrospective Study. Transplant Int Off J Eur Soc Organ Transplant (2018) 31(4):424-35. doi: 10.1111/tri.13106

134. Choi S, Lee KW, Park JB, Kim K, Jang HR, Huh W, et al. C3d-Positive Preformed DSAs Tend to Persist and Result in a Higher Risk of AMR After Kidney Transplants. J Clin Med (2020) 9(2). doi: 10.3390/jcm9020375

135. Yell M, Muth BL, Kaufman DB, Djamali A, Ellis TM. C1q Binding Activity of De Novo Donor-Specific HLA Antibodies in Renal Transplant Recipients With and Without Antibody-Mediated Rejection. Transplantation (2015) 99 (6):1151-5. doi: 10.1097/TP.0000000000000699

136. Eculizumab Therapy for Subclinical Antibody-Mediated Rejection in Kidney Transplantation.

137. Eculizumab for Prevention of Delayed Graft Function (DGF) in Kidney Transplantation.

138. Eculizumab to Enable Renal Transplantation in Patients With History of Catastrophic Antiphospholipid Antibody Syndrome.

139. Eculizumab to Prevent Antibody-Mediated Rejection in ABO Blood Group Incompatible Living Donor Kidney Transplantation.

140. Eculizumab Therapy for Chronic Complement-Mediated Injury in Kidney Transplantation.

141. Dosing Regimen of Eculizumab Added to Conventional Treatment in Positive Cross Match Living Donor Kidney Transplant.

142. A Study of the Activity of Eculizumab for Prevention of Delayed Graft Function In Deceased Donor Kidney Transplant.

143. Dosing Regimen of Eculizumab Added to Conventional Treatment in Positive Crossmatch Deceased Donor Kidney Transplant.

144. Efficacy and Safety of Eculizumab for Treatment of Antibody-Mediated Rejection Following Renal Transplantation.

145. Safety \& Efficacy of Eculizumab to Prevent AMR in Living Donor Kidney Transplant Recipients Requiring Desensitization.

146. Marks WH, Mamode N, Montgomery RA, Stegall MD, Ratner LE, Cornell LD, et al. Safety and Efficacy of Eculizumab in the Prevention of Antibody-
Mediated Rejection in Living-Donor Kidney Transplant Recipients Requiring Desensitization Therapy: A Randomized Trial. Am J Transplant (2019) 19(10):2876-88. doi: 10.1111/ajt.15364

147. Safety \& Efficacy Of Eculizumab In The Prevention Of AMR In Sensitized Recipients Of A Kidney Transplant From A Deceased Donor.

148. Prevention of Delayed Graft Function Using Eculizumab Therapy (PROTECT Study).

149. Eculizumab for Prevention and Treatment of Kidney Graft Reperfusion Injury.

150. Recombinant Human C1 Inhibitor for the Treatment of Early AntibodyMediated Rejection in Renal Transplantation.

151. Vo AA, Zeevi A, Choi J, Cisneros K, Toyoda M, Kahwaji J, et al. A Phase I/II Placebo-Controlled Trial of C1-Inhibitor for Prevention of AntibodyMediated Rejection in HLA Sensitized Patients. Transplantation (2015) 99 (2):299-308. doi: 10.1097/TP.0000000000000592

152. Safety \& Tolerability of Berinert 6 (C1 Inhibitor) Therapy to Prevent Rejection.

153. CIINH Inhibitor Preoperative and Post Kidney Transplant to Prevent DGF \& IRI.

154. C1-Inhibitor (INH) for Refractory Antibody Mediated Renal Allograft Rejection.

155. Efficacy and Safety of Human Plasma-Derived C1-Esterase Inhibitor as Addon to Standard of Care for the Treatment of Refractory Antibody Mediated Rejection (AMR) in Adult Renal Transplant Recipients.

156. Viklicky O, Slatinska J, Novotny M, Hruba P. Developments in Immunosuppression. Curr Opin Organ Transplant (2021) 26(1):91-6. doi: 10.1097/MOT.0000000000000844

157. A Multicenter Study to Evaluate the Efficacy and Safety of Cinryze $₫$ for the Treatment of Acute Antibody-Mediated Rejection in Participants With Kidney Transplant.

158. A Pilot Study to Evaluate the Use of C1 Esterase Inhibitor (Human) in Patients With Acute Antibody-Mediated Rejection.

159. Montgomery RA, Orandi BJ, Racusen L, Racusen L, Jackson AM, GaronzikWang JM, Shah T, et al. Plasma-Derived C1 Esterase Inhibitor for Acute Antibody-Mediated Rejection Following Kidney Transplantation: Results of a Randomized Double-Blind Placebo-Controlled Pilot Study. Am J Transplant (2016) 16(12):3468-78. doi: 10.1111/ajt.13871

160. Berinert (CIINH) vs Placebo for DGF/IRI.

161. RUCONEST6」 as a Therapeutic Strategy to Reduce the Incidence of Delayed Graft Function.

162. CINRYZE as a Donor Pre-Treatment Strategy in Kidney Recipients of $K D P I>60 \%$.

163. Portilla D, Xavier S. Role of Intracellular Complement Activation in Kidney Fibrosis. Br J Pharmacol (2021) 178(14):2880-91. doi: 10.1111/bph.15408

164. Chen NJ, Mirtsos C, Suh D, Lu YC, Lin WJ, McKerlie C, et al. C5L2 is Critical for the Biological Activities of the Anaphylatoxins C5a and C3a. Nature (2007) 446(7132):203-7. doi: 10.1038/nature05559

165. Li L, Chen L, Zang J, Tang X, Liu Y, Zhang J, et al. C3a and C5a Receptor Antagonists Ameliorate Endothelial-Myofibroblast Transition via the Wnt/ $\beta$-Catenin Signaling Pathway in Diabetic Kidney Disease. Metabolism (2015) 64(5):597-610. doi: 10.1016/j.metabol.2015.01.014

166. Gu H, Fisher AJ, Mickler EA, Duerson F3rd, Cummings OW, Peters-Golden $\mathrm{M}$, et al. Contribution of the Anaphylatoxin Receptors, C3aR and C5aR, to the Pathogenesis of Pulmonary Fibrosis. FASEB J Off Publ Fed Am Soc Exp Biol (2016) 30(6):2336-50. doi: 10.1096/fj.201500044

167. Chmilewsky F, About I, Chung SH. Pulp Fibroblasts Control Nerve Regeneration Through Complement Activation. J Dental Res (2016) 95 (8):913-22. doi: 10.1177/0022034516643065

168. Chmilewsky F, Ayaz W, Appiah J, About I, Chung SH. Nerve Growth Factor Secretion From Pulp Fibroblasts is Modulated by Complement C5a Receptor and Implied in Neurite Outgrowth. Sci Rep (2016) 6:31799. doi: 10.1038/srep31799

169. Rufas P, Jeanneau C, Rombouts C, Laurent P, About I. Complement C3a Mobilizes Dental Pulp Stem Cells and Specifically Guides Pulp Fibroblast Recruitment. J Endod (2016) 42(9):1377-84. doi: 10.1016/j.joen.2016.06.011

170. Su S, Chen J, Yao H, Liu J, Yu S, Lao L, et al. CD10(+)GPR77(+) CancerAssociated Fibroblasts Promote Cancer Formation and Chemoresistance by Sustaining Cancer Stemness. Cell (2018) 172(4):841-856.e816. doi: 10.1016/ j.cell.2018.01.009 
171. Niu N, Yao J, Bast RC, Sood AK, Liu J. IL-6 Promotes Drug Resistance Through Formation of Polyploid Giant Cancer Cells and Stromal Fibroblast Reprogramming. Oncogenesis (2021) 10(9):65. doi: 10.1038/s41389-02100349-4

172. Friščić J, Böttcher M, Reinwald C, Bruns H, Wirth B, Popp SJ, et al. The Complement System Drives Local Inflammatory Tissue Priming by Metabolic Reprogramming of Synovial Fibroblasts. Immunity (2021) 54 (5):1002-1021.e1010. doi: 10.1016/j.immuni.2021.03.003

173. Weitz M, Amon O, Bassler D, Koenigsrainer A, Nadalin S. Prophylactic Eculizumab Prior to Kidney Transplantation for Atypical Hemolytic Uremic Syndrome. Pediatr Nephrol (Berlin Germany) (2011) 26(8):1325-9. doi: 10.1007/s00467-011-1879-9

174. Siedlecki AM, Isbel N, Vande Walle J, James Eggleston J, Cohen DJ. Eculizumab Use for Kidney Transplantation in Patients With a Diagnosis of Atypical Hemolytic Uremic Syndrome. Kidney Int Rep (2019) 4(3):43446. doi: 10.1016/j.ekir.2018.11.010

175. Lonze BE, Zachary AA, Magro CM, Desai NM, Orandi BJ, Dagher NN, et al. Eculizumab Prevents Recurrent Antiphospholipid Antibody Syndrome and Enables Successful Renal Transplantation. Am J Transplant (2014) 14 (2):459-65. doi: 10.1111/ajt.12540

176. Lonze BE, Singer AL, Montgomery RA. Eculizumab and Renal Transplantation in a Patient With CAPS. New Engl J Med (2010) 362 (18):1744-5. doi: 10.1056/NEJMc0910965

177. Garg N, Zhang Y, Nicholson-Weller A, Khankin EV, Borsa NG, Meyer NC, et al. C3 Glomerulonephritis Secondary to Mutations in Factors H and I: Rapid Recurrence in Deceased Donor Kidney Transplant Effectively Treated With Eculizumab. Nephrol Dial Transplant Off Publ Eur Dialysis Transplant Assoc - Eur Renal Assoc (2018) 33(12):2260-5. doi: 10.1093/ndt/gfx369

178. Schröppel B, Akalin E, Baweja M, Bloom RD, Florman S, Goldstein M, et al. Peritransplant Eculizumab Does Not Prevent Delayed Graft Function in Deceased Donor Kidney Transplant Recipients: Results of Two Randomized Controlled Pilot Trials. Am J Transplant (2020) 20(2):564-72. doi: 10.1111/ ajt. 15580

179. Berger M, Baldwin WM3rd, Jordan SC. Potential Roles for C1 Inhibitor in Transplantation. Transplantation (2016) 100(7):1415-24. doi: 10.1097/ TP.0000000000000995

180. Danobeitia JS, Zens TJ, Chlebeck PJ, Zitur LJ, Reyes JA, Eerhart MJ, et al. Targeted Donor Complement Blockade After Brain Death Prevents Delayed Graft Function in a Nonhuman Primate Model of Kidney Transplantation. Am J Transplant (2020) 20(6):1513-26. doi: 10.1111/ajt.15777

181. Jordan SC, Choi J, Aubert O, Haas M, Loupy A, Huang E, et al. A Phase I/II, Double-Blind, Placebo-Controlled Study Assessing Safety and Efficacy of C1 Esterase Inhibitor for Prevention of Delayed Graft Function in Deceased Donor Kidney Transplant Recipients. Am J Transplant (2018) 18(12):295564. doi: 10.1111/ajt.14767

182. Huang E, Vo A, Choi J, Ammerman N, Lim K, Sethi S, et al. Three-Year Outcomes of a Randomized, Double-Blind, Placebo-Controlled Study Assessing Safety and Efficacy of C1 Esterase Inhibitor for Prevention of Delayed Graft Function in Deceased Donor Kidney Transplant Recipients. Clin J Am Soc Nephrol (2020) 15(1):109-16. doi: 10.2215/CJN.04840419

183. van Zanden JE, Jager NM, Daha MR, Erasmus ME, Leuvenink HGD, Seelen MA. Complement Therapeutics in the Multi-Organ Donor: Do or Don't? Front Immunol (2019) 10:329. doi: 10.3389/fimmu.2019.00329

184. Röth A, Nishimura JI, Nagy Z, Gaal-Weisinger J, Panse J, Yoon SS, et al. The Complement C5 Inhibitor Crovalimab in Paroxysmal Nocturnal Hemoglobinuria. Blood (2020) 135(12):912-20. doi: 10.1182/blood.2019003399

185. Latuszek A, Liu Y, Olsen O, Foster R, Cao M, Lovric I, et al. Inhibition of Complement Pathway Activation With Pozelimab, a Fully Human Antibody to Complement Component C5. PloS One (2020) 15(5):e0231892. doi: 10.1371/journal.pone.0231892

186. Adams AB, Lovasik BP, Faber DA, Burlak C, Breeden C, Estrada JL, et al. Anti-C5 Antibody Tesidolumab Reduces Early Antibody-Mediated Rejection and Prolongs Survival in Renal Xenotransplantation. Ann Surg (2021) 274(3):473-80. doi: 10.1097/SLA.0000000000004996

187. Kulasekararaj AG, Hill A, Rottinghaus ST, Langemeijer S, Wells R, GonzalezFernandez FA, et al. Ravulizumab (ALXN1210) vs Eculizumab in C5Inhibitor-Experienced Adult Patients With PNH: The 302 Study. Blood (2019) 133(6):540-9. doi: 10.1182/blood-2018-09-876805

188. McKeage K. Ravulizumab: First Global Approval. Drugs (2019) 79(3):34752. doi: 10.1007/s40265-019-01068-2

189. Schols S, Nunn MA, Mackie I, Weston-Davies W, Nishimura JI, Kanakura Y, et al. Successful Treatment of a PNH Patient non-Responsive to Eculizumab With the Novel Complement C5 Inhibitor Coversin (Nomacopan). Br J Haematol (2020) 188(2):334-7. doi: 10.1111/bjh.16305

190. Badri P, Jiang X, Borodovsky A, Najafian N, Kim J, Clausen VA, et al. Pharmacokinetic and Pharmacodynamic Properties of Cemdisiran, an RNAi Therapeutic Targeting Complement Component 5, in Healthy Subjects and Patients With Paroxysmal Nocturnal Hemoglobinuria. Clin Pharmacokinet (2021) 60(3):365-78. doi: 10.1007/s40262-020-00940-9

191. de Castro C, Grossi F, Weitz IC, Maciejewski J, Sharma V, Roman E, et al. C3 Inhibition With Pegcetacoplan in Subjects With Paroxysmal Nocturnal Hemoglobinuria Treated With Eculizumab. Am J Hematol (2020) 95 (11):1334-43. doi: 10.1002/ajh.25960

192. Hillmen P, Szer J, Weitz I, Roth A, Hochsmann B, Panse J, et al. Pegcetacoplan Versus Eculizumab in Paroxysmal Nocturnal Hemoglobinuria. New Engl J Med (2021) 384(11):1028-37. doi: 10.1056/ NEJMoa2029073

193. Risitano AM, Kulasekararaj AG, Lee JW, Maciejewski JP, Notaro R, Brodsky R, et al. Danicopan: An Oral Complement Factor D Inhibitor for Paroxysmal Nocturnal Hemoglobinuria. Haematologica (2021) 106(12):3188-97. doi: 10.3324/haematol.2020.261826

194. Risitano AM, Röth A, Soret J, Frieri C, de Fontbrune FS, Marano L, et al. Addition of Iptacopan, an Oral Factor B Inhibitor, to Eculizumab in Patients With Paroxysmal Nocturnal Haemoglobinuria and Active Haemolysis: An Open-Label, Single-Arm, Phase 2, Proof-of-Concept Trial. Lancet Haematol (2021) 8(5):e344-54. doi: 10.1016/S2352-3026(21)00028-4

195. Tesar V, Hruskova Z. Avacopan in the Treatment of ANCA-Associated Vasculitis. Expert Opin Invest Drugs (2018) 27(5):491-6. doi: 10.1080/ 13543784.2018.1472234

Conflict of Interest: The authors declare that the research was conducted in the absence of any commercial or financial relationships that could be construed as a potential conflict of interest.

Publisher's Note: All claims expressed in this article are solely those of the authors and do not necessarily represent those of their affiliated organizations, or those of the publisher, the editors and the reviewers. Any product that may be evaluated in this article, or claim that may be made by its manufacturer, is not guaranteed or endorsed by the publisher.

Copyright (C) 2022 Qi and Qin. This is an open-access article distributed under the terms of the Creative Commons Attribution License (CC BY). The use, distribution or reproduction in other forums is permitted, provided the original author(s) and the copyright owner(s) are credited and that the original publication in this journal is cited, in accordance with accepted academic practice. No use, distribution or reproduction is permitted which does not comply with these terms. 